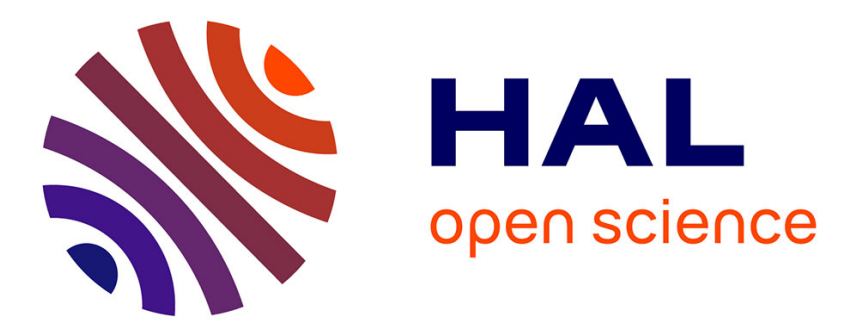

\title{
Conception of novel blue crab chitosan films crosslinked with different saccharides via the Maillard reaction with improved functional and biological properties
}

\author{
Marwa Hamdi, Rim Nasri, Youssra Ben Azaza, S.M. Li, Moncef Nasri
}

\section{- To cite this version:}

Marwa Hamdi, Rim Nasri, Youssra Ben Azaza, S.M. Li, Moncef Nasri. Conception of novel blue crab chitosan films crosslinked with different saccharides via the Maillard reaction with improved functional and biological properties. Carbohydrate Polymers, 2020, 241, pp.116303. 10.1016/j.carbpol.2020.116303 . hal-03093136

\section{HAL Id: hal-03093136 \\ https://hal.science/hal-03093136}

Submitted on 22 Feb 2021

HAL is a multi-disciplinary open access archive for the deposit and dissemination of scientific research documents, whether they are published or not. The documents may come from teaching and research institutions in France or abroad, or from public or private research centers.
L'archive ouverte pluridisciplinaire HAL, est destinée au dépôt et à la diffusion de documents scientifiques de niveau recherche, publiés ou non, émanant des établissements d'enseignement et de recherche français ou étrangers, des laboratoires publics ou privés. 
archives-ouvertes

\title{
Conception of novel blue crab chitosan films crosslinked with different saccharides via the Maillard reaction with improved functional and biological properties
}

\author{
Rim Nasri, Youssra Azaza, Suming Li, Moncef Nasri, Marwa Hamdi
}

\section{To cite this version:}

Rim Nasri, Youssra Azaza, Suming Li, Moncef Nasri, Marwa Hamdi. Conception of novel blue crab chitosan films crosslinked with different saccharides via the Maillard reaction with improved functional and biological properties. Carbohydrate Polymers, Elsevier, 2020, 241, 10.1016/j.carbpol.2020.116303 . hal-03093136

\section{HAL Id: hal-03093136 \\ https://hal.archives-ouvertes.fr/hal-03093136}

Submitted on 22 Feb 2021

HAL is a multi-disciplinary open access archive for the deposit and dissemination of scientific research documents, whether they are published or not. The documents may come from teaching and research institutions in France or abroad, or from public or private research centers.
L'archive ouverte pluridisciplinaire HAL, est destinée au dépôt et à la diffusion de documents scientifiques de niveau recherche, publiés ou non, émanant des établissements d'enseignement et de recherche français ou étrangers, des laboratoires publics ou privés. 


\section{Conception of novel blue crab chitosan films crosslinked with}

2 different saccharides via the Maillard reaction with improved

\section{functional and biological properties.}

4 Marwa Hamdi ${ }^{a^{*}}, \operatorname{Rim}_{\text {Nasri }}{ }^{\mathrm{a}, \mathrm{b}}$, Youssra Ben Azaza ${ }^{\text {a }}$, Suming $\mathrm{Li}^{\mathrm{c}}$, Moncef Nasri $^{\text {a }}$

5 a Laboratory of Enzyme Engineering and Microbiology, University of Sfax, National Engineering School of Sfax,

6 B.P. 1173, 3038 Sfax, Tunisia.

$7 \quad{ }^{b}$ Higher Institute of Biotechnology of Monastir, University of Monastir, Monastir, Tunisia.

$8{ }^{c}$ European Institute of Films, UMR CNRS 5635, University of Montpellier, Place Eugene Bataillon, 34095

9 Montpellier Cedex 5, France.

10

11

12

* Corresponding author: Marwa Hamdi, Laboratory of Enzyme Engineering and Microbiology, University of Sfax, National Engineering School of Sfax, B.P. 1173, 3038 Sfax, Tunisia. Tel: 21625740373 / 216 54186612; E-mail: marwahamdi50@yahoo.fr. 


\section{Abstract}

This work aimed to modify blue crab chitosan-based films through the Maillard reaction (MR) as a novel alternative to improve their functional and biological properties. To this end, different saccharides (glucose (aldohexose), fructose (ketohexose), xylose (aldopentose) and arabinose (aldopentose)), at different weight ratios $0.5,1.0$ and $2.0 \%$ (g/100 g polymer), were studied, and films were heated at $90{ }^{\circ} \mathrm{C}$ for $24 \mathrm{~h}$. Based on color changes and browning index measurements, the extent of MR was the highest with aldopentoses, whereas hexoses and particularly ketohexoses, exhibited a relative crosslinking rate. These findings were further reflected with an improvement in treated films mechanical properties and thermal degradation temperatures, and advantageously, barrier properties against UV light and water. In addition, the MR-modified Cs-based films antioxidant activity was interestingly enhanced with mainly aldopentoses. Consequently, MR crosslinked chitosan-based films are promising alternative for active and functional packaging able of food oxidation hindering, especially using aldopentoses.

Keywords: Chitosan; Films; Crosslinking; Maillard reaction; In vitro characterization. 


\section{Introduction}

Nowadays, there has been several concerns towards the alarming natural resources lessening, health and environmental hitches of petroleum-based synthetic polymers, traditionally and massively used in medical and food industries (Al Jahwari and Pervez, 2019; Liu et al., 2019; Sponchioni, Palmiero and Moscatelli, 2019). Therefore, intensive researches, in the field of food protection, has focused on the conception of a natural and non-toxic coating material, able of effectively enhancing the shelf-life of fresh or packaged commercialized food, as alternative to synthetic films (Assadpour and Jafari, 2019; Galiano et al., 2018).

These bio-based packaging should be able to perfectly hinder the UV radiation, prevent oxidative damages and encounter food-borne pathogens developpement, for the protection of food and extending their shelf life, without ideally loss of their mechanical integrity and behavior characteristics (Vilela et al., 2017). Among most studied biopolymers, chitosan is an inspiring and propitious polymer, of a polysaccharide nature, competently applied as an alternative in agriculture, food and pharmaceutical industries (Vukajlovic, Parker, Bretcanu and Novakovic, 2019; Shariatinia, 2018). Although the applicability of chitosan-based biomaterials is knowing a noteworthy increase (Zhai, Bai, Zhu, Wang and Luo, 2018), still certain physicochemical properties of the chitosan-based films are deficient and require, thereby, to be amended in order to feat industrial needs, such as light and water barrier properties, since packaging materials' water content and light (UV specially) transmission basically affected packaged or coated materials' shelf life), as well mechanical resistance (Akyuz et al., 2017). In fact, regarding materials applied or expected for food packaging, mechanical properties evaluation is mandatory for shaping their performance to sustain several sorts of stresses occurring during packaging applications processes.

Several types of treatments can be used for the modification of edible films, in order to improve their structural properties (such as sensitivity to water), barrier characteristics (light 
barrier and water vapor or gas permeability), biological properties (i.e. antioxidant and antimicrobial activities), etc., including the combination of two polymers, physical treatments such as heat treatment and irradiation and biochemical treatments such as the Maillard reaction (MR) (Mujtaba et al., 2019; Kamboj, Singh, Tiwary and Rana, 2015).

Given the good antioxidant and antibacterial activities of MR products in food industry, their use as a preservative is attracting increasing interest (Sung, Chang, Chou and Hsiao, 2018; Cai et al., 2016; Gullon et al., 2016; Wu et al., 2014). The MR, also called non-enzymatic browning, is a chemical reaction of browning of amino acids in the presence of sugars (Umemura and Kawai, 2007). MR is the main reaction responsible for the transformation of precursors into dyes and flavoring compounds during food processing and preservation $(\mathrm{Xu}$, Huang, Xu, Liu and Xiao, 2019), which can be influenced by many factors, including reagent concentration, temperature, heating time, initial $\mathrm{pH}$, and reagent characteristics.

In a previous work (Hamdi, Nasri, Li and Nasri, 2019a), the improvement of the barrier, mechanical and biological properties of blue crab chitosan-based films was envisaged, by incorporation of carotenoproteins used both as polymers and antioxidant and antimicrobial agents. The addition of carotenoproteins at $15 \%(\mathrm{w} / \mathrm{w} \mathrm{Cs}$ ) in the blue crab chitosan film-forming matrix allowed an improvement in the barrier, color, thermal and biological (antioxidant and antimicrobial) properties. However, a reduction in their mechanical resistance was noted. Thus, the present work is interested in a novel alternative to improve the physical and biological properties of blue crab chitosan-based films, by complex crosslinking coupled with a heat treatment. Indeed, recently, researches regarding modifying proteins properties through the MR revealed that protein-saccharide grafts are advantageous as an innovative functional biopolymer with excellent emulsifying, antioxidant and antimicrobial properties for food and pharmaceutical applications (Kchaou et al., 2018). 
Although many studies, dealing with chitosan-based films (Fernandez-de Castro et al., 2016; Rubentheren et al., 2016; Leceta, Guerrero, Ibarburu, Dueñas and de la Caba, 2013) and chitosan-MR (Wang, Liu, Liang, Yuan and Gao, 2014; Lakshmi Kosaraju, Weerakkody and Augustin, 2010; Umemura and Kawai, 2008), have been performed, and the factors affecting the reaction, including sugar concentration, temperature and reaction time have been evaluated (Gullon et al., 2016), there are no many previous reports on the effect of saccharides type/chemical structure on the physicochemical and antioxidant properties of films based on chitosans and different types of saccharides. Therefore, in the present work, we have chosen to compare the reactivity of chitosan with different mono-saccharides, glucose (aldohexose), fructose (ketohexose), xylose (aldopentose) and arabinose (aldopentose), at different weight ratios $0.5,1.0$ and $2.0 \%(\mathrm{~g} / 100 \mathrm{~g}$ polymer).

\section{Materials and methods}

\subsection{Materials}

D-anhydrous-glucose $\left(\mathrm{C}_{6} \mathrm{H}_{12} \mathrm{O}_{6} ; 180 \mathrm{~g} \mathrm{~mol}^{-1}\right)$, D-anhydrous fructose $\left(\mathrm{C}_{6} \mathrm{H}_{12} \mathrm{O}_{6} ; 180 \mathrm{~g}\right.$ mol $\left.^{-1}\right)$, L-anhydrous-arabinose $\left(\mathrm{C}_{5} \mathrm{H}_{10} \mathrm{O}_{5} ; 150 \mathrm{~g} \mathrm{~mol}^{-1}\right)$ and L-anhydrous-xylose $\left(\mathrm{C}_{5} \mathrm{H}_{10} \mathrm{O}_{5} ; 150\right.$ g mol${ }^{-1}$ ), purchased from Sigma-Aldrich (France), were applied as reducing sugar for the Maillard reaction initiation in Cs-based films. In the present work, the other used chemical reagents from commercial sources were of analytical grade and employed without further purifications.

\subsection{Extraction of blue crab chitosan}

Chitosan (Cs), with acetylation degree of $8 \%$, as characterized by ${ }^{13} \mathrm{C}$ NMR, molecular weight $\mathrm{Mw}$ of $115 \mathrm{kDa}$ and intrinsic viscosity [ $\eta]$ of $3432 \mathrm{ml} / \mathrm{g}$, based on the size exclusion chromatography, was obtained from blue crab shells chitin, through $\mathrm{N}$-deacetylation with $\mathrm{NaOH}$ 
$12.5 \mathrm{M}$, at a ratio of $1 / 10(\mathrm{w} / \mathrm{v})$, for $4 \mathrm{~h}$ at $140{ }^{\circ} \mathrm{C}$, as reported in our previous study (Hamdi $e t$ al., 2018).

\subsection{Preparation of Cs-based MR-treated films}

Film-forming solutions were prepared by dissolving Cs at a concentration of $2 \%(\mathrm{w} / \mathrm{v})$ in aqueous solution of acetic acid 0.15 M. Then, sugars (glucose, fructose, arabinose and xylose) were added under gentle stirring at different concentrations $(0.5,1.0$ and $2.0 \%$; w/w dry Cs matter). Glycerol was added as a plasticizer to the film-forming solutions at a concentration of $15 \%$ (w/w dry Cs matter). After stirring for $24 \mathrm{~h}$ at $25^{\circ} \mathrm{C}$ and degassing, film-forming solutions were left standing for $12 \mathrm{~h}$ at $25^{\circ} \mathrm{C}$ and centrifuged for $10 \mathrm{~min}$ at $8000 \mathrm{~g}$. Thereafter, films were prepared by casting film-forming solutions $(25 \mathrm{ml})$ on Petri dishes $(13.5 \mathrm{~cm}$ diameter $)$ and were left to dry for $48 \mathrm{~h}$ at $25^{\circ} \mathrm{C}$, until complete solvent evaporation.

The well-dried films were peeled from the plate and heated for $24 \mathrm{~h}$ in an oven at a temperature of $90 \pm 2{ }^{\circ} \mathrm{C}$ and an average relative humidity (RH) value of approximatively $30 \%$, to apply the heat-treatment for MR induction. Non-heated films are considered as controls and saccharide-free chitosan film is considered as blank. Finally, all designed films were maintained at $25^{\circ} \mathrm{C}$ at a $\mathrm{RH}$ of $50 \%$, for subsequent characterizations.

\subsection{Analytical methods}

\subsubsection{Films thickness}

The thickness of prepared films was measured by using a micrometer (Digimatic IP65, Mitutoyo, France), reporting the average value of 5-6 measurements taken at random locations. Thickness results were taken into account for mechanical properties.

\subsubsection{Films moisture content}

Water content (WC) of prepared films was performed in an oven at $105{ }^{\circ} \mathrm{C}$, where samples (approximately $100 \mathrm{mg}$ ) were dried until constant weight was reached (sample dry 
weight). The moisture content of films was determined by measuring the mass loss of each film in triplicate and expressed as follows [21]:

$$
\mathrm{WC}(\%)=\frac{\mathrm{M}_{0}-\mathrm{M}_{1}}{\mathrm{M}_{0}} \times 100
$$

where $\mathrm{M}_{0}$ and $\mathrm{M}_{1}$ are respective weights $(\mathrm{g})$ of films before and after drying.

\subsubsection{Films water solubility}

Films solubility in water was determined in triplicate based on the method reported by Gennadios, Handa, Froning, Weller and Hanna (1998). Film samples (2 cm x $5 \mathrm{~cm}$; about 100 $\mathrm{mg}$ ), previously weighed, were immersed in $30 \mathrm{ml}$ distilled water containing $0.1 \%(\mathrm{w} / \mathrm{v})$ antimicrobial agent (sodium azide), for $24 \mathrm{~h}$ at $25^{\circ} \mathrm{C}$. Afterwards, tubes containing film samples were centrifuged at $3000 \mathrm{~g}, 25^{\circ} \mathrm{C}$ for $10 \mathrm{~min}$. Supernatants were removed, and solubilized film portion was estimated by drying the obtained undissolved debris, at $105^{\circ} \mathrm{C}$ for $24 \mathrm{~h}$. Water solubility (WS) was determined according the following equation:

$$
\operatorname{WS}(\%)=\frac{\left[\mathrm{M}_{\mathrm{i}} \times(100-\mathrm{WC})-\mathrm{M}_{\mathrm{f}}\right]}{\mathrm{M}_{\mathrm{i}} \times(100-\mathrm{WC})} \times 100
$$

where $\mathrm{M}_{\mathrm{i}}$ and $\mathrm{M}_{\mathrm{f}}$ are initial and final respective masses (g) of films and WC is water content of each film sample (\%).

\subsubsection{Films water contact angle}

A goniometer (Drop Shape Analyzer 30 from Kruss $\mathrm{GmbH}$ ), equipped with an image analysis software (ADVANCE) was used for the study of the films water contact angle (WCA), considering the sessile drop method. Briefly, a droplet of water (approximatively $2 \mathrm{ml}$ ) was dropped on the film surface using a precision syringe, in an environmental chamber with a constant environment at a temperature of $25 \pm 2{ }^{\circ} \mathrm{C}$ and a $\mathrm{RH}$ of $50 \%$. WCA, expressed as ${ }^{\circ}$, 
was measured on both sides of the drop and the average of five measurements was determined and reported.

\subsubsection{Films water vapor permeability}

The gravimetric method, adapted by Debeaufort, Martin-Polo and Voilley (1993) for hydrophilic polymers, was applied for the determination of films water vapor permeability (WVP). First, to permit films equilibration, samples were conditioned at $25{ }^{\circ} \mathrm{C}$ and $50 \% \mathrm{RH}$ for a minimum equilibration time of $48 \mathrm{~h}$. Films thickness measurements values and statistical error were considered in the WVP measurements. WVP calculations were based on maintaining film samples between two Teflon rings at the glass cell upper. The WVP cell containing $\mathrm{KCl}$ saline solution (100\% RH), was placed into a climatic chamber (KBF 240 Binder, ODIL, France) maintained at $25{ }^{\circ} \mathrm{C}$ and a $\mathrm{RH}$ of $30 \%$. Once the equilibrium state was reached, the value of WVP $\left(\mathrm{g} \mathrm{m}^{-1} \mathrm{~s}^{-1} \mathrm{~Pa}^{-1}\right)$ was calculated, based on the change in the absolute value of the weight loss as a function of time, as follows:

$$
\operatorname{WVP}\left(\mathrm{g} \mathrm{m}^{-1} \mathrm{~s}^{-1} \mathrm{~Pa}^{-1}\right)=\frac{\Delta \mathrm{m}}{\Delta \mathrm{t}} \times \frac{1}{\mathrm{~A}} \times \frac{1}{\Delta \mathrm{p}} \times \mathrm{e}
$$

where $\Delta \mathrm{m} / \Delta \mathrm{t}$ is the weight of moisture loss per unit of time $(\mathrm{g} / \mathrm{s}), \mathrm{A}$ is the film area exposed to the transfer $\left(1.39 \times 10^{4} \mathrm{~m}^{2}\right)$, e is the film thickness $(\mathrm{m})$, and $\Delta \mathrm{p}$ is the water vapor partial pressure differential between the two sides of the film $(\mathrm{Pa})$.

\subsubsection{Optical properties of films}

\subsubsection{Color features}

Films color parameters were measured, using a portable colorimeter (Minolta Chroma Meter CR-300, CIE, 1976) and the color was recorded using the color parameters CIE L* $\mathrm{a}^{*}$ $\mathrm{b}^{*}$. L* indicates transparency and its value varies from 0 (black) to 100 (white), a* is a measure of green $\left(-a^{*}\right) /$ redness $\left(+a^{*}\right)$ and $b^{*}$ is the measure of blue $\left(-b^{*}\right) /$ yellow $\left(+b^{*}\right)$. The 
colorimeter was calibrated against a standard Minolta standard reflector plate before each actual color measurement. In addition, for the derived color parameters, the total color difference $(\Delta \mathrm{E})$, of prepared films were calculated using the following equations:

$$
\Delta \mathrm{E}=\sqrt{\left(\mathrm{L}^{*}-\mathrm{L}_{0}{ }^{*}\right)^{2}+\left(\mathrm{a}^{*}-\mathrm{a}_{0}{ }^{*}\right)^{2}+\left(\mathrm{b}^{*}-\mathrm{b}_{0}\right)^{2}}
$$

where $\mathrm{L}_{0} *, \mathrm{a}_{0} *, \mathrm{~b}_{0} *$ are the colorimetric parameters of the standard are $\left(\mathrm{L}^{*}=97.25, \mathrm{a}^{*}=-0.2\right.$ and $\left.b^{*}=2.25\right)$ and $L^{*}, a^{*}, b^{*}$ are the values for the films obtained. The $C$ axis represents Chroma (or saturation). It ranges from 0 , which is completely unsaturated (neutral gray, black or white) to 100 for very high Chroma (saturation) or purity of color.

\subsubsection{Maillard-treated films browning index}

Films browning index (BI) was determined, as reported by Matiacevich and Pilar Buera (2006), based on the CIE L* $\mathrm{a}^{*} \mathrm{~b}^{*}$ values, using the following equation:

$$
\mathrm{BI}=\frac{100(z-0.31)}{0.172}
$$

where,

$$
z=a+1.75(L) / 5.645(L)+a-3.012(b)
$$

\subsubsection{Films $U V$ barrier and transparency properties}

The transmittance spectra $(200-800 \mathrm{~nm})$ of the developed films were made using a UVVisible spectrophotometer (T70, UV/vis spectrometer, PG Instruments Ltd., China). Thus, the films are cut to obtain rectangles of $1 \mathrm{~cm} \times 3 \mathrm{~cm}$ and directly placed in the test cell of the spectrophotometer. Air was used as a reference. This measurement aims to evaluate the barrier effect of UV films and to determine their transparency, considering the following equation:

$$
\operatorname{Transparency}(\%)=\frac{-\log \mathrm{T}_{600}}{\mathrm{e}}
$$


where $\mathrm{T}_{600}$ is the fractional transmittance at $600 \mathrm{~nm}$ and e is the thickness $(\mathrm{mm})$ of the films. The lower transparency of the film is reflected by a greater transparency value.

\subsubsection{Infrared spectroscopy analysis}

The FT-IR spectra of the prepared were performed using a spectrometer (Agilent Technologies, Carry 630 series) equipped with an attenuated reflection accessory (ATR) containing a diamond/ZnSe crystal, at room temperature $\left(25^{\circ} \mathrm{C}\right)$ in the spectral range frequencies of $650-4000 \mathrm{~cm}^{-1}$. For each spectrum, 32 scans of interferograms were averaged and the spectral resolution was $4 \mathrm{~cm}^{-1}$. Data analysis and treatment was carried out by using the OMNIC Spectra software (ThermoFisher Scientific).

\subsubsection{Films thermal properties}

\subsubsection{Differential Scanning Calorimeter analysis}

Differential Scanning Calorimeter (Modulated DSC Q20, TA Instruments), equipped with a liquid nitrogen cooling system, was used to investigate the thermal properties of prepared films, allowing the estimation of melting and crystallization point, as well as the glass transition of the macromolecular materials. Film samples were accurately weighed into aluminum pans and sealed. An empty capsule served as an inert reference and the apparatus was calibrated using indium. The thermal profile of chitosan samples was analyzed in a temperature range of 0-225 ${ }^{\circ} \mathrm{C}$, at a heating rate scan of $10{ }^{\circ} \mathrm{C} / \mathrm{min}$, under nitrogen flow rate of $50 \mathrm{ml} / \mathrm{min}$. Thermograms were then analyzed by using TA Universal V4.5A software.

\subsubsection{Thermogravimetric analysis}

Thermogravimetric analysis (TGA Q500 High Resolution, TA Instruments), operating under nitrogen flow, was used to study the thermal stability of Cs-based MR-treated films. The progressive change in mass $(\%)$ as a function of temperature, is recorded. Thus, films (approximatively $4 \mathrm{mg}$ ) were heated from 25 to $700{ }^{\circ} \mathrm{C}$ at a heating rate of $20{ }^{\circ} \mathrm{C} / \mathrm{min}$ and 
constantly measured with an accuracy of $0.01 \mathrm{mg}$. Cs-based films thermograms were subsequently recorded, analyzed and treated using the TA Universal V4.5A software (TA Instruments, Waters, New Castle, UK).

\subsubsection{Films mechanical properties}

Films mechanical properties were investigated based on the determination of the tensile strength (TS, MPa) and elongation at break (EAB, \%) parameters. A rheometer apparatus (Physica MCR, Anton Paar, GmbH, France) equipped with mechanical properties measuring geometry was used. To this end, films rectangular samples $(1.0 \mathrm{~cm} \times 4.5 \mathrm{~cm})$ were cut with an accurate width and parallel sides throughout the entire length.

Prior to analysis, all the films samples were equilibrated at $25^{\circ} \mathrm{C}$ and $50 \% \mathrm{RH}$ for two weeks and their thickness were measured. Based on the ISO standard, equilibrated films samples, retained in the extension grips of the measuring system, were subjected to a uniaxial tensile test, with a deformation rate of $5 \mathrm{~mm} / \mathrm{min}$ until breaking. Rheoplus software was used for the estimation of TS and EAB, corresponding respectively to the maximum load and the final extension at break from the stress-strain curves. Average values from at least six measurements were reported.

\subsubsection{Films microstructure}

The cross-section of films was determined using scanning electron microscopy (SEM) (Hitachi S4800), at an angle of $90^{\circ}$ to the surface. Prior to imaging the film cross-section, film samples were cryofractured by immersion in liquid nitrogen, cut and fixed on the SEM support using double side adhesive tape, under an accelerating voltage of $2.0 \mathrm{kV}$ and an absolute pressure of $60 \mathrm{~Pa}$, after sputter coating with a $5 \mathrm{~nm}$ thick gold.

\subsection{Films antioxidant potential}

\subsubsection{1,1-diphenyl-2-picrylhydrazyl (DPPH) radicals scavenging ability}


The ability of films (10 mg) to scavenge DPPH radical was determined according to the method of Bersuder, Hole and Smith (1998). The absorbance change, at $517 \mathrm{~nm}$ between the control and the sample, was used to calculate the scavenging activity. DPPH radical-scavenging activity of Cs-based MR-treated films was evaluated and computed considering the following equation:

$$
\text { DPPH Radical scavenging activity }(\%)=\frac{A_{C}+A_{B}-A_{R}}{A_{C}} \times 100
$$

where $A_{C}$ is the absorbance of the control reaction, $A_{R}$ and $A_{B}$ were the absorbances of Csbased films in the reaction mixture and without addition of DPPH solution, respectively. Results were expressed as means of experiments performed in duplicate.

\subsubsection{Reducing power activity assay}

The ability of films (10 mg) to reduce iron (III) was determined according to the method of Yildirim, Mavi and Kara (2001). The absorbance of the resulting solutions was measured at $700 \mathrm{~nm}$, after incubation at room temperature for $10 \mathrm{~min}$. Higher absorbance of the reaction mixture indicated higher reducing power. The test was carried out in duplicate and BHA was used as a standard.

\subsubsection{Metal-chelating activity}

The chelating activity of films $(10 \mathrm{mg})$ towards ferrous ion $\left(\mathrm{Fe}^{2+}\right)$ was studied as reported by Decker and Welch (1990). EDTA was used as reference and the chelating activity (\%) was computed using the following equation:

$$
\text { Chelating activity }(\%)=\frac{A_{C}+A_{B}-A_{R}}{A_{C}} \times 100
$$

where $A_{C}$ is the absorbance of the control reaction, $A_{R}$ and $A_{B}$ were the absorbance of Cs-based films in the reaction mixture and without addition of Ferrozine solution, respectively. Results were expressed as means of experiments performed in duplicate. 


\subsection{Statistical analysis}

All experiments were carried out in duplicate, excepting films mechanical properties, where analysis was repeated at least six times, and average values with standard deviation errors were reported. Mean separation and significance were analyzed using the SPSS software package ver. 17.0 professional edition (SPSS, Inc., Chicago, IL, USA) using ANOVA analysis. Differences between the different Cs-based films crosslinked with the different saccharides and heated or not at $90{ }^{\circ} \mathrm{C}$ for $24 \mathrm{~h}$, were considered significant at $\mathrm{p}<0.05$.

\section{Results and Discussion}

\subsection{Water resistance and barrier features of Cs-based films as influenced by the MR}

\subsubsection{Water content measurement}

Packaged or coated materials' shelf life is affected by packaging materials' WC (Kchaou et al., 2018). WC values (Fig. 1A) reveal that, for non-heated Cs-based films, humidity values increased from $20 \%$ for blank (non-added) Cs-based film to $24 \%$ for $2.0 \%$ (w/w Cs) crosslinked Cs-saccharides films ( $\mathrm{p}<0.05)$, independently of the added saccharide (aldose or ketose, pentose or hexose). However, at concentrations of 0.5 and $1.0 \%$ (w/w Cs), no significant differences were noted $(p>0.05)$. The very well-known hygroscopicity of saccharides could explain the increase of WC of the non-heated Cs-saccharides films (Hazaveh, Mohammadi Nafchi and Abbaspour, 2015).

After induction of the MR (heat treatment at $90{ }^{\circ} \mathrm{C}$ for $24 \mathrm{~h}$ ), WC decreased gradually with the increase of saccharide content from $0.5 \%$ (w/w Cs) to $2.0 \%$ (w/w Cs), depending on the type of the saccharide used $(\mathrm{p}<0.05)$, due to the interaction between the amino groups of $\mathrm{Cs}$ and the carbonyl groups of the tested saccharide, resulting in polar groups decrease and the disruption of Cs-water interactions due to hampering of the hydroxyl and amino groups availability (Rui et al., 2017). In fact, regarding the Cs-arabinose crosslinked films, the WC dropped to $18.15 \%, 17.08 \%$ and $16.38 \%$ at $0.5,1.0$ and $2.0 \%$ (w/w Cs), which could be 
explained by free water loss from MR-treated films after being heated at $90{ }^{\circ} \mathrm{C}$. Moreover, the

following order of reactivity could be observed: fructose $<$ glucose $<$ xylose $<$ arabinose. For example, at a concentration of $2.0 \%$ (w/w Cs), after heat treatment, the WC values reached $16.38 \%, 16.73 \%, 17.92 \%$ and $18.39 \%$, for Cs-arabinose, Cs-xylose, Cs-glucose and Cs-fructose crosslinked films, respectively, vs. $18.37 \%$ for blank Cs-based film.

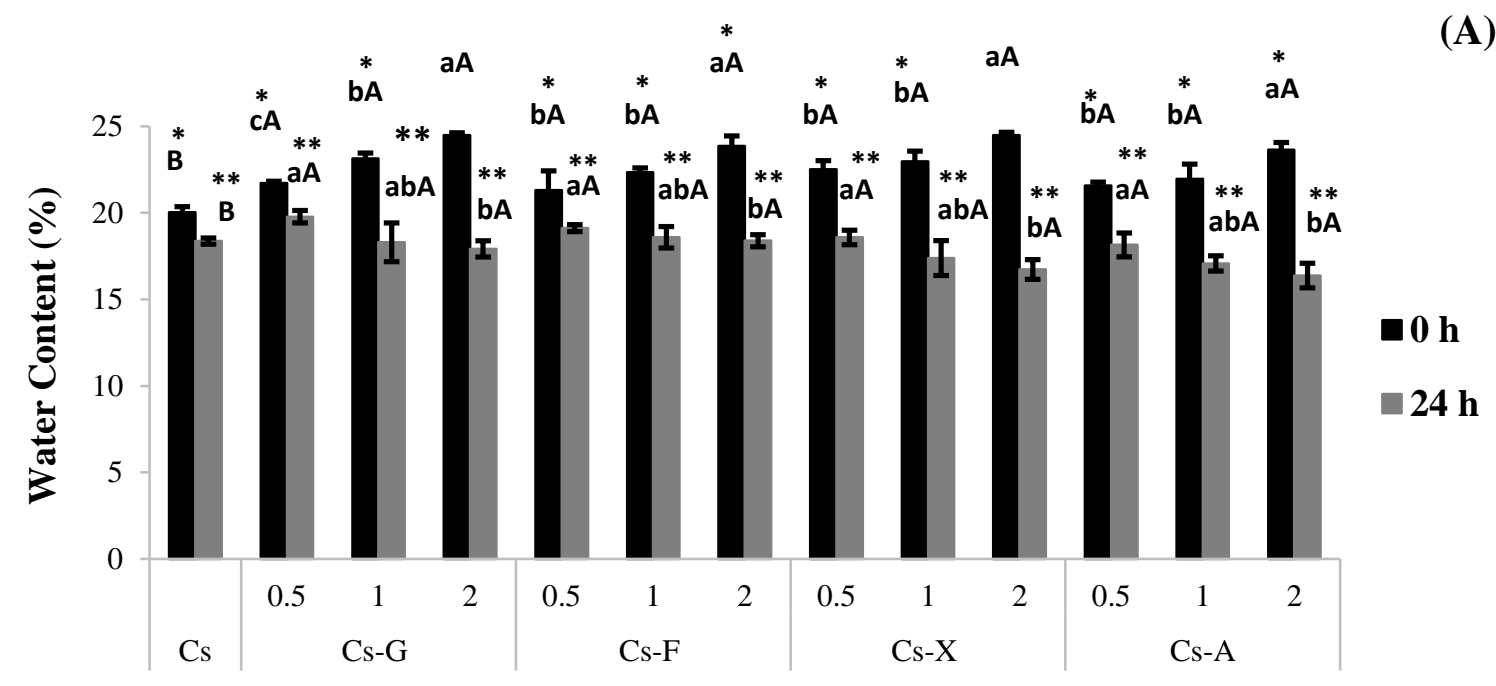

Film formulations

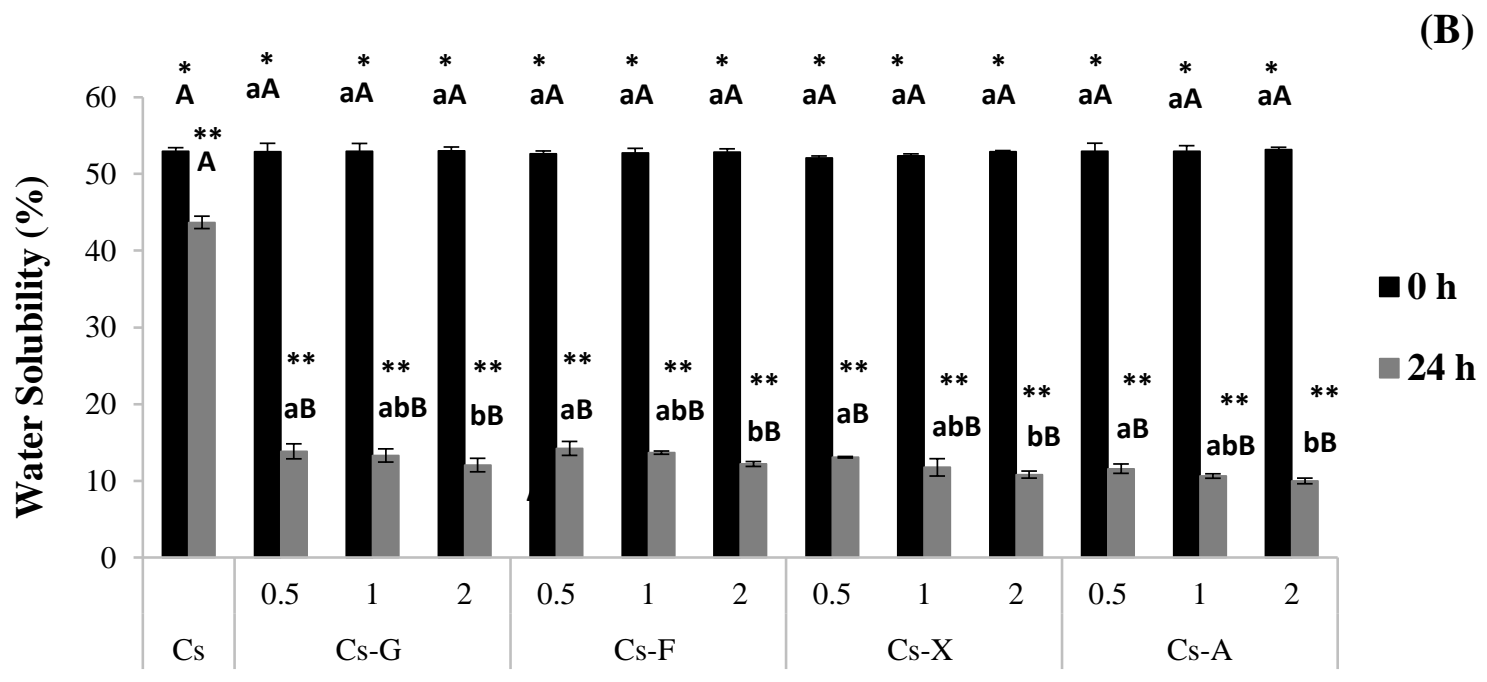

Film formulations

Figure 1: Water content (WC\%) (A) and water solubility (WS\%) (B) of Cs-based films conjugated with different saccharides, at different mass ratios $(0.5,1.0$ and $2.0 \%$; w/w Cs), through MR at $90{ }^{\circ} \mathrm{C}$ as a function of time (0 and 24 h). Cs: Chitosan, A: Arabinose, F: Fructose, G: Glucose, $\mathbf{X}$ : Xylose. Different letters ${ }^{(a-c)}$ in the same films group are significantly different as determined by ANOVA test $(\mathrm{p}<0.05)$. Different letters ${ }^{(\mathbf{A}-\mathbf{B})}$ indicated significant differences between different films groups at the same heating time $(\mathrm{p}<0.05)$. Different symbols ${ }^{(* * *)}$ indicated significant differences between heated and nonheated films for the same group $(\mathrm{p}<0.05)$. 
This finding suggested that the extent of the MR, as reflected by films water content decrease, was influenced by the type of saccharides, where pentoses (arabinose and xylose), with less carbons in their macromolecular chain, showed more reactivity, compared to the hexoses (fructose and glucose), with more carbons (Gullon et al., 2016). Particularly, aldoses (arabinose, xylose and glucose), with a carbonyl group located at one end of the carbon chain, were more reactive than ketoses (fructose), with a carbonyl group situated inside the carbon chain, resulting in the lowest WC values after crosslinking with aldopentoses, proving higher covalent crosslinking extent and lower polar groups availability.

\subsubsection{Study of water solubility}

Films WS, related with the biomaterial hydrophobicity/hydrophilicity, is a crucial feature defining biopolymeric-based films applications. WS results, shown in Fig. 1B, highlight that blank Cs-based film was sensitive to water, exhibiting WS of $52 \%$. For the non-heated Cssaccharides films, WS values were maintained constant, independently of the type and dose of added saccharide, compared to the blank Cs-based film ( $p>0.05)$. However, as expected, due to the crosslinking, films WS decreased significantly with the heat treatment for the different Cssaccharide ratios $(\mathrm{p}<0.05)$. For example, after $24 \mathrm{~h}$ MR time, WS reached values of $11.58 \%$, $10.62 \%$ and $9.98 \%$ for Cs-arabinose mass ratios of $0.5,1.0$ and $2.0 \%$ (w/w Cs), respectively, vs. 43.69 for blank Cs-based film heated at $90{ }^{\circ} \mathrm{C}$ for $24 \mathrm{~h}$. Compared to blank film, when added to the Cs film-forming solution, overall tested saccharides acted as crosslinking agent, permitting the creation of covalent bonds with the Cs polymeric matrix, and thereby, the decrease of WS values (Kamboj et al., 2015). In fact, the principal mechanisms of MR are the formation of the initial products, called Schiff bases, which form Amadori products via rearrangement. These latter undergo further reactions to form irreversible advanced glycation end products, called melanoidins (Kchaou et al., 2018). 
Moreover, WS decrease was saccharide dose dependent. In fact, WS of films with higher saccharide contents $(2.0 \%, \mathrm{w} / \mathrm{w} \mathrm{Cs})$, and thereby, higher crosslinking rate, decreased more rapidly, compared to films with relative crosslinking degree, as a result of lower saccharide content $(0.5 \%, \mathrm{w} / \mathrm{w} \mathrm{Cs})$.

As predicted, MR was more facilitated with pentoses and aldoses than hexoses and ketoses, knowing that higher crosslinking resulted in lower the solubility. For $2.0 \%$ (w/w Cs), Cs-arabinose MR-treated films displayed the lowest WS values of 9.98\%, followed by Csxylose, Cs-glucose and Cs-fructose MR-treated films ( $\mathrm{p}<0.05)$, with respective WS of $10.81 \%$, $12.05 \%$ and $12.19 \%$ (Fig. 1B). Average WS values of 52\% were initially recorded for nonheated films. This increase in MR-treated films insolubility in water, depending on the type and dose of added saccharide, could be the result of higher covalent crosslinking extent, particularly in the presence of aldopentoses. More precisely, this higher WS of the resulting films due to higher glycation rate (the extent of crosslinking between amino groups of Cs and the carbonyl groups of the tested saccharide) could be ascribed to the formation of melanoidins (heterogeneous brown polymers of high molecular weight), non-soluble MR compounds (Stevenson et al., 2020).

Based on the latter outcomes, MR, mainly via crosslinking with aldopentoses, could be considered as effective alternative allowing the amelioration of Cs-based films water resistance in terms of their insolubility in water.

\subsubsection{Water contact angle determination}

One of the common ways to measure the wettability (resistance to water absorption) of films surface is the determination of WCA, indicating, the hydrophilicity/hydrophobicity degree of films (Etxabide, Uranga, Guerrero and de la Caba, 2015). Obtained data are reported in Table 1 and Supplementary Data Fig. S1. 
Table 1: Water contact angle (WCA), water vapor (WVP) permeability, tensile strength (TS) and elongation at break (EAB) of Cs-based MR-treated films, compared to the non-modified control film.

\begin{tabular}{|c|c|c|c|c|c|c|}
\hline \multirow{2}{*}{\multicolumn{2}{|c|}{ Film formulations }} & \multirow{2}{*}{$\begin{array}{l}\text { MR heating } \\
\text { time (h) }\end{array}$} & \multirow{2}{*}{$\begin{array}{c}\text { WCA } \\
\left({ }^{\circ}\right)\end{array}$} & \multirow{2}{*}{$\begin{array}{c}\text { WVP } \\
10^{-10} \\
\left(\mathrm{~g} \mathrm{~m}^{-1} \mathrm{~s}^{-1} \mathrm{~Pa}^{-1}\right)\end{array}$} & \multirow{2}{*}{$\begin{array}{c}\text { TS } \\
(\mathrm{MPa})\end{array}$} & \multirow{2}{*}{$\begin{array}{r}\text { EAB } \\
(\%)\end{array}$} \\
\hline & & & & & & \\
\hline \multirow{2}{*}{\multicolumn{2}{|c|}{ Cs }} & 0 & $92.4 \pm 0.6^{\mathrm{aA}}$ & $3.6 \pm 0.1^{\mathrm{aB}}$ & $18.9 \pm 0.5^{\mathrm{aA}}$ & $29.6 \pm 0.4^{\mathrm{aA}}$ \\
\hline & & 24 & $91.5 \pm 0^{\mathrm{aH}}$ & $3.4 \pm 0.3^{\mathrm{aA}}$ & $18.7 \pm 0.9 \mathrm{aF}$ & $29.8 \pm 0.8^{\mathrm{aF}}$ \\
\hline \multirow{6}{*}{ Cs-G } & \multirow{2}{*}{0.5} & 0 & $92.8 \pm 0.2^{\mathrm{aA}}$ & $3.8 \pm 0.9^{\mathrm{aAB}}$ & $18.6 \pm 0.4^{\mathrm{aA}}$ & $29.9 \pm 0.7^{\mathrm{aA}}$ \\
\hline & & 24 & $100.8 \pm 1^{\mathrm{bG}}$ & $3 \pm 0.4^{\mathrm{aA}}$ & $19.7 \pm 0.3^{\mathrm{aE}}$ & $30 \pm 1^{\mathrm{Ae}}$ \\
\hline & \multirow{2}{*}{1.0} & 0 & $91.4 \pm 1^{\mathrm{aA}}$ & $4.2 \pm 0.1 \mathrm{aA}$ & $18.3 \pm 0.9 \mathrm{aA}$ & $29.7 \pm 0.8$ aA \\
\hline & & 24 & $104.6 \pm 0.5^{\mathrm{cF}}$ & $1.9 \pm 0.1 \mathrm{bBC}$ & $21.5 \pm 0.2^{b D}$ & $31.1 \pm 0^{\mathrm{aD}}$ \\
\hline & \multirow{2}{*}{2.0} & 0 & $93.7 \pm 1.3^{\mathrm{aA}}$ & $4.3 \pm 0.7 \mathrm{aAB}$ & $19.9 \pm 1.5^{\mathrm{aA}}$ & $29.3 \pm 0.6^{\mathrm{aA}}$ \\
\hline & & 24 & $109.4 \pm 0.4^{\mathrm{dF}}$ & $1.1 \pm 0.2^{\mathrm{cC}}$ & $23.3 \pm 0.3^{\mathrm{cB}}$ & $33.6 \pm 0.5^{\mathrm{bBC}}$ \\
\hline \multirow{6}{*}{ Cs-F } & \multirow{2}{*}{0.5} & 0 & $92.4 \pm 0.6^{\mathrm{aA}}$ & $3.9 \pm 0.3^{\mathrm{aAB}}$ & $18.4 \pm 0.6^{\mathrm{aA}}$ & $29.6 \pm 0.3^{\mathrm{aA}}$ \\
\hline & & 24 & $91.2 \pm 1.2^{\mathrm{aH}}$ & $2.9 \pm 0.3^{\mathrm{aA}}$ & $19.3 \pm 0.2^{\mathrm{cE}}$ & $29.5 \pm 0.9^{a F}$ \\
\hline & \multirow{2}{*}{1.0} & 0 & $92.2 \pm 0.2^{\mathrm{aA}}$ & $4.8 \pm 0.2^{\mathrm{aA}}$ & $18.5 \pm 1.1^{\mathrm{aA}}$ & $29.9 \pm 1.4$ aA \\
\hline & & 24 & $101.2 \pm 0.5^{\mathrm{bG}}$ & $2.1 \pm 0.2 \mathrm{bB}$ & $21.1 \pm 0.5^{\mathrm{bD}}$ & $29.7 \pm 1.2^{\mathrm{aF}}$ \\
\hline & \multirow{2}{*}{2.0} & 0 & $91.2 \pm 0.9^{\mathrm{aA}}$ & $4.9 \pm 0.5^{\mathrm{aA}}$ & $18.9 \pm 0.9^{\mathrm{aA}}$ & $29.8 \pm 0.6^{\mathrm{aA}}$ \\
\hline & & 24 & $105 \pm 1.5^{\mathrm{cF}}$ & $1.4 \pm 0.3^{\mathrm{cC}}$ & $22.8 \pm 0.1^{\mathrm{cC}}$ & $32.9 \pm 0.3^{\mathrm{bC}}$ \\
\hline \multirow{6}{*}{ Cs-X } & \multirow{2}{*}{0.5} & 0 & $91.2 \pm 0.9^{\mathrm{aA}}$ & $4.1 \pm 0.8^{\mathrm{aAB}}$ & $19.9 \pm 1.5^{\mathrm{aA}}$ & $29.6 \pm 0.6^{\mathrm{aA}}$ \\
\hline & & 24 & $108.9 \pm 0.1^{\mathrm{bE}}$ & $2.3 \pm 0.1 \mathrm{aB}$ & $19.4 \pm 0^{\mathrm{aE}}$ & $29.5 \pm 0.2^{\mathrm{aF}}$ \\
\hline & \multirow{2}{*}{1.0} & 0 & $92.8 \pm 0.2^{\mathrm{aA}}$ & $4.5 \pm 0.2^{\mathrm{aA}}$ & $18.3 \pm 1.2^{\mathrm{aA}}$ & $29.3 \pm 1.1^{\mathrm{aA}}$ \\
\hline & & 24 & $111.6 \pm 0.4^{\mathrm{cD}}$ & $1.6 \pm 0.4^{\mathrm{bBC}}$ & $22.4 \pm 0.1^{\mathrm{bC}}$ & $32.7 \pm 0.6^{\mathrm{bC}}$ \\
\hline & \multirow{2}{*}{2.0} & 0 & $93.9 \pm 0.9^{\mathrm{aA}}$ & $4.2 \pm 0.4^{\mathrm{aAB}}$ & $18.9 \pm 0.2^{\mathrm{aA}}$ & $29.4 \pm 0.4$ aA \\
\hline & & 24 & $113.8 \pm 0.4^{\mathrm{dC}}$ & $1.4 \pm 0.3 \mathrm{bC}$ & $24.9 \pm 0.4^{\mathrm{cB}}$ & $34.8 \pm 0.3^{\mathrm{cB}}$ \\
\hline \multirow{6}{*}{ Cs-A } & \multirow{2}{*}{0.5} & 0 & $92.6 \pm 0.8^{\mathrm{aA}}$ & $4.6 \pm 0.2^{\mathrm{aA}}$ & $18.7 \pm 0.8^{\mathrm{aA}}$ & $29.1 \pm 0.7^{\mathrm{aA}}$ \\
\hline & & 24 & $109.2 \pm 0.4^{\mathrm{bE}}$ & $1.8 \pm 0.4 \mathrm{aBC}$ & $21.2 \pm 0.6^{\mathrm{aD}}$ & $32.1 \pm 1.1^{\mathrm{aC}}$ \\
\hline & \multirow{2}{*}{1.0} & 0 & $91.4 \pm 0.6^{\mathrm{aA}}$ & $4.4 \pm 0.6^{\mathrm{aAB}}$ & $19.2 \pm 0.7^{\mathrm{aA}}$ & $29.8 \pm 0.6^{\mathrm{aA}}$ \\
\hline & & 24 & $115.2 \pm 1^{\mathrm{cB}}$ & $1.4 \pm 0.2^{\mathrm{aC}}$ & $23.8 \pm 0.2^{\mathrm{bB}}$ & $34.9 \pm 0.9^{\mathrm{bB}}$ \\
\hline & \multirow{2}{*}{2.0} & 0 & $93.2 \pm 0.7^{\mathrm{aA}}$ & $4.6 \pm 0.1^{\mathrm{aA}}$ & $19 \pm 0.2^{\mathrm{aA}}$ & $30 \pm 0.4 \mathrm{aA}$ \\
\hline & & 24 & $118.4 \pm 1.5^{\mathrm{dA}}$ & $1.2 \pm 0.2^{\mathrm{aC}}$ & $26.7 \pm 0.8^{\mathrm{cA}}$ & $37.1 \pm 0.8^{\mathrm{cA}}$ \\
\hline
\end{tabular}


No significant difference was shown regarding the WCA of non-heated films and for MRtreated Cs-fructose films at a mass ratio of $0.5 \%$ (w/w Cs), with an average WCA value of 92 ${ }^{\circ}$ ( $\left.p>0.05\right)$. Subsequently, overall Cs-based films could be considered as hydrophobic films. Apart from that, as a result of Cs-saccharide MR crosslinking, WCA increased in a saccharide dose dependent manner $(\mathrm{p}<0.05)$, which could be attributed to the decrease in the hydrophilic character of heated films, as a result of polar groups decrease. For example, in the case of Csarabinose MR treated films, WCA values of $109^{\circ}, 115^{\circ}$ and $118^{\circ}$ were noted at mass ratios of $0.5,1.0$ and $2.0 \%$ (w/w Cs), respectively. As well, WCA increased from $100{ }^{\circ}$ to $109^{\circ}$ and from $108^{\circ}$ to $113^{\circ}$, for Cs-xylose and Cs-glucose mass ratios of $0.5 \%$ and $2.0 \%$ (w/w Cs), respectively.

Taking into consideration these outcomes, the increase in films surface hydrophobicity, reflected by higher WCA values, was the most pronounced in the case of MR crosslinking with aldopentoses (arabinose and xylose), whereas, ketosis (fructose) was the less reactive, showing a relative crosslinking extent, after films heating at $90{ }^{\circ} \mathrm{C}$ for $24 \mathrm{~h}$.

\subsubsection{Water vapor permeability assessment}

The effect of the MR crosslinking on the water barrier properties of Cs-based films was studied, considering films WVP $\left(10^{-10} \mathrm{~g} \mathrm{~m}^{-1} \mathrm{~s}^{-1} \mathrm{~Pa}^{-1}\right)$ measured at $100 \% \mathrm{RH}$ and results are summarized in Table 1. No significant differences in the WVP values were noted for the nonheated and heated free-saccharide Cs-based film, as well as non-heated saccharides-added films ( $>0.05)$. However, WVP of heated films significantly decreased with the addition of saccharides to the film forming solutions, compared to the blank Cs-based film $\left(3.410^{-10} \mathrm{~g} \mathrm{~m}^{-1}\right.$ $\left.\mathrm{s}^{-1} \mathrm{~Pa}^{-1}\right)$. This decrease was saccharide type and dose dependent, where films crosslinked with aldopentoses (less carbons in their macromolecular chain, with a carbonyl group at the end of the carbon chain) displayed the lowest WVP $(\mathrm{p}<0.05)$. Values of $1.410^{-10} \mathrm{~g} \mathrm{~m}^{-1} \mathrm{~s}^{-1} \mathrm{~Pa}^{-1}$ and 1.6 $10^{-10} \mathrm{~g} \mathrm{~m}^{-1} \mathrm{~s}^{-1} \mathrm{~Pa}^{-1}$ were reached with $1.0 \%$ (w/w Cs) of arabinose and xylose, respectively. The 
lowest reactivity, expressed in terms of the highest WVP value of $2.110^{-10} \mathrm{~g} \mathrm{~m}^{-1} \mathrm{~s}^{-1} \mathrm{~Pa}^{-1}$, was observed with the Cs-fructose crosslinked films (ketosis), at the same concentration. Additionally, WVP decreased from 1.8 to $1.210^{-10} \mathrm{~g} \mathrm{~m}^{-1} \mathrm{~s}^{-1} \mathrm{~Pa}^{-1}$, when the concentration of arabinose increased from 0.5 to $2.0 \%$ (w/w Cs). The same trend was noted with the xylose, fructose and glucose $(\mathrm{p}<0.05)$.

The decrease in the WVP could be ascribed to the reduction of the films network free volume (films pore size), subsequently to the MR crosslinking. This allowed a sufficient strengthening of the polymeric network, and thereby, the enhancement of Cs-MR-treated films mechanical properties. Therefore, a significant effect on the diffusion of water, among very small molecules (Hazaveh et al., 2015). Serrano-Leon et al. (2018) stated that the film barrier properties are affected by the filmogenic matrix moisture content. Indeed, a decrease in water concentration results in a decrease in molecular chains' mobility, ultimately changing permeability behavior of the MR-treated films.

\subsection{Effect of the MR on films color and light barrier properties}

\subsubsection{Study of films color parameters}

Optical features, including color, besides physicochemical and thermal behavior, are a key character to substantiate the effectiveness of packaging intended to food applications (Jiang et al., 2016). Visually, no significant modification was noted regarding non-heated blank and Cs-saccharides films color (Supplementary Data Fig. S2). Whereas, the color of MR crosslinked films shifted from colorless to dark yellow to variable extent, depending on the type and dose of incorporated saccharide. Therefore, changes in color of blank and MR-treated Csbased films were determined and shown in Table 2. $\mathrm{L}^{*}$ (whiteness/darkness), a* (redness/greenness) and $b^{*}$ (yellowness/blueness) values were used for the quantification of films color. Higher $\mathrm{L}^{*}$, negative $\mathrm{a}^{*}$ and $\mathrm{b}^{*}$ values imply lightness, green and blue color, respectively, while positive $\mathrm{a}^{*}$ and $\mathrm{b}^{*}$ values indicate red and yellow color, respectively. 
In the present study, $\mathrm{L}^{*}$ values decreased with the increase of saccharide content in the

Cs-film forming solution, reaching a minimum of $85 \%$ in the presence of $2.0 \%$ (w/w Cs) of arabinose, after a $24 \mathrm{~h}$ heating time at $90{ }^{\circ} \mathrm{C}(\mathrm{p}<0.05)$. Values of $88 \%$ and $87 \%$ were revealed with arabinose mass ratios of 0.5 and $1.0 \%$ (w/w Cs). While, negligible variations of lightness were detected for non-heated films and even for heated blank film ( $p>0.05)$, proving that color was not mainly affected by heating. The higher $\mathrm{L}^{*}$ were displayed in the presence of fructose (ketosis), showing relative crosslinking rate, since the developpement of dark products is correlated with the extent of Cs-saccharide interaction through the MR. L* values of $90 \%, 89 \%$ and $88 \%$ were recorded for $0.5,1.0$ and $2.0 \%$ (w/w Cs) mass ratios of fructose. Lipid oxidation and food quality are mainly influenced by packaging material opacity, which is a key feature to substantiate the effectiveness of packaging intended to food applications as a protective agent of food materials from degradative effects of light. Indeed, light, specifically UV light, is mainly involved in the oxidation process, by chemical reactions catalyzation, which accelerates the deterioration of food, affecting ultimately its acceptability by the consumer (Su et al., 2012). In addition, MR led to a significant intensification of Cs-based films dark yellowish color as illustrated by $b^{*}$ values measurements (Table 2). Indeed, $b^{*}$ increased significantly from 3.6 for blank Cs-based film to 10.9, 21.5, 25.7 and 31.6 for $2.0 \%$ (w/w Cs) content of fructose, glucose, xylose and arabinose, respectively. Even at the least mass ratio of $0.5 \%(\mathrm{w} / \mathrm{w})$, a significant and rapid improvement in films yellowish color, by 2, 2.4, 2.6 and 3-folds, was observed for fructose, glucose, xylose and arabinose, respectively. In line with $\mathrm{L}^{*}$ results, ketosis (fructose) was the least reactive, while aldopentoses (particularly arabinose) showed the highest MR crosslinking extent. A different tendency was noted regarding the $\mathrm{a}^{*}$ coordinates, where values decreased toward the green region with MR crosslinking, depending on the saccharide type and dose (Table 2). Equally, no significant changes were detected for the nonheated films and the blank Cs-based film ( $p>0.05)$. 
Table 2: Color parameters, browning index (BI) and transparency of Cs-based MRtreated films, compared to the non-modified control film.

\begin{tabular}{|c|c|c|c|c|c|c|c|c|}
\hline \multirow{2}{*}{\multicolumn{2}{|c|}{ Film formulations }} & \multirow{2}{*}{$\begin{array}{c}\text { MR } \\
\text { heating } \\
\text { time }(h)\end{array}$} & \multicolumn{4}{|c|}{ Color parameters } & \multirow{2}{*}{ BI } & \multirow{2}{*}{ Transparency } \\
\hline & & & $\mathbf{L}^{*}$ & $\mathbf{a}^{*}$ & $\mathbf{b}^{*}$ & $\Delta \mathbf{E}$ & & \\
\hline \multirow{2}{*}{\multicolumn{2}{|c|}{ Cs }} & 0 & $91.2 \pm 0.4^{\mathrm{aA}}$ & $2.4 \pm 0.1^{\mathrm{aA}}$ & $3.6 \pm 0.3^{\mathrm{aA}}$ & \multirow{2}{*}{ - } & \multirow{2}{*}{ - } & $0.9 \pm 0.1^{\mathrm{aA}}$ \\
\hline & & 24 & $91.2 \pm 0.4^{\mathrm{aA}}$ & $2.4 \pm 0.1^{\mathrm{aA}}$ & $3.6 \pm 0.3^{\mathrm{aA}}$ & & & $1 \pm 0.1^{\mathrm{aA}}$ \\
\hline \multirow{6}{*}{ Cs-G } & \multirow{2}{*}{0.5} & 0 & $91.3 \pm 0.7^{\mathrm{aA}}$ & $2.4 \pm 0.2^{\mathrm{aA}}$ & $3.6 \pm 0.6^{\mathrm{aA}}$ & - & - & $0.9 \pm 0^{\mathrm{aA}}$ \\
\hline & & 24 & $89.1 \pm 0.1^{\mathrm{bC}}$ & $-0.9 \pm 0^{\mathrm{bB}}$ & $8.8 \pm 0.4^{\mathrm{bC}}$ & $5.9 \pm 1 \mathrm{cBC}$ & $9.3 \pm 0.5^{\mathrm{aC}}$ & $2.6 \pm 0.1^{\mathrm{bC}}$ \\
\hline & \multirow{2}{*}{1.0} & 0 & $91.8 \pm 0.3^{\mathrm{aA}}$ & $2.3 \pm 0.1^{\mathrm{aA}}$ & $3.4 \pm 0.5^{\mathrm{aA}}$ & - & - & $0.9 \pm 0.1^{\mathrm{aA}}$ \\
\hline & & 24 & $88.5 \pm 0.1^{\mathrm{cC}}$ & $-1.4 \pm 0.1^{\mathrm{cC}}$ & $11.3 \pm 0.7^{\mathrm{cC}}$ & $9.1 \pm 0.6^{\mathrm{bC}}$ & $12 \pm 0.8^{\mathrm{bC}}$ & $3.8 \pm 0.1^{\mathrm{cD}}$ \\
\hline & \multirow{2}{*}{2.0} & 0 & $91.2 \pm 0.4^{\mathrm{aA}}$ & $2.3 \pm 0.5^{\mathrm{aA}}$ & $3.5 \pm 0.2^{\mathrm{aA}}$ & - & - & $1 \pm 0.1^{\mathrm{aA}}$ \\
\hline & & 24 & $87.1 \pm 0.4^{\mathrm{dC}}$ & $-2.1 \pm 0 \mathrm{dC}$ & $21.5 \pm 1 \mathrm{dC}$ & $19 \pm 0.8^{\mathrm{aC}}$ & $25.5 \pm 1.3^{\mathrm{cC}}$ & $4 \pm 0^{\mathrm{dC}}$ \\
\hline \multirow{6}{*}{ Cs-F } & \multirow{2}{*}{0.5} & 0 & $91.3 \pm 0.5^{\mathrm{aA}}$ & $2.4 \pm 0.8^{\mathrm{aA}}$ & $3.6 \pm 0.3^{\mathrm{aA}}$ & - & - & $0.9 \pm 0.2^{\mathrm{aA}}$ \\
\hline & & 24 & $90.6 \pm 0.2^{\mathrm{bB}}$ & $-0.9 \pm 0.1^{\mathrm{bB}}$ & $7.5 \pm 0.4^{\mathrm{bB}}$ & $5.1 \pm 0.4^{\mathrm{cC}}$ & $7.6 \pm 0.4^{\mathrm{cD}}$ & $2.3 \pm 0.2^{\mathrm{bC}}$ \\
\hline & \multirow{2}{*}{1.0} & 0 & $91.6 \pm 0.9$ aA & $2.5 \pm 0.1^{\mathrm{aA}}$ & $3.4 \pm 0.4^{\mathrm{aA}}$ & - & - & $0.9 \pm 0$ aA \\
\hline & & 24 & $89.5 \pm 0.2^{\mathrm{cB}}$ & $-1.2 \pm 0.1^{\mathrm{cB}}$ & $9.2 \pm 0.3^{\mathrm{cB}}$ & $7 \pm 0.3^{\mathrm{bD}}$ & $9.5 \pm 0.3^{\mathrm{bD}}$ & $3.5 \pm 0.1^{\mathrm{cC}}$ \\
\hline & \multirow{2}{*}{2.0} & 0 & $90.9 \pm 0.6^{\mathrm{aA}}$ & $2.5 \pm 0.4^{\mathrm{aA}}$ & $3.5 \pm 0.7^{\mathrm{aA}}$ & - & - & $1 \pm 0.1^{\mathrm{aA}}$ \\
\hline & & 24 & $88.2 \pm 0.1^{\mathrm{dB}}$ & $-1.4 \pm 0.1 \mathrm{~dB}$ & $10.9 \pm 0.6^{\mathrm{dB}}$ & $8.8 \pm 0.5^{\mathrm{aD}}$ & $11.5 \pm 0.7 \mathrm{aD}$ & $4 \pm 0.1 \mathrm{dC}$ \\
\hline \multirow{6}{*}{ Cs-X } & \multirow{2}{*}{0.5} & 0 & $91.3 \pm 0.8^{\mathrm{aA}}$ & $2.4 \pm 0.2^{\mathrm{aA}}$ & $3.6 \pm 0.3^{\mathrm{aA}}$ & - & - & $1 \pm 0.1^{\mathrm{aA}}$ \\
\hline & & 24 & $88.6 \pm 0.1^{\mathrm{bD}}$ & $-0.9 \pm 0^{\mathrm{bB}}$ & $9.4 \pm 0.3^{\mathrm{bC}}$ & $7.2 \pm 0.3^{\mathrm{cB}}$ & $10.1 \pm 0.3^{\mathrm{cB}}$ & $3 \pm 0^{\mathrm{bB}}$ \\
\hline & \multirow{2}{*}{1.0} & 0 & $92 \pm 0.7^{\mathrm{aA}}$ & $2.4 \pm 0.1^{\mathrm{aA}}$ & $3.6 \pm 0.2^{\mathrm{aA}}$ & - & - & $1 \pm 0.1^{\mathrm{aA}}$ \\
\hline & & 24 & $87.2 \pm 0.1^{\mathrm{cD}}$ & $-2.7 \pm 0.1^{\mathrm{cD}}$ & $13 \pm 0.4^{\mathrm{cD}}$ & $11.5 \pm 0.4^{\text {bВ }}$ & $13.3 \pm 0.8^{\mathrm{bB}}$ & $4.7 \pm 0.1^{\mathrm{cB}}$ \\
\hline & \multirow{2}{*}{2.0} & 0 & $92.1 \pm 0.9^{\mathrm{aA}}$ & $2.5 \pm 0.3^{\mathrm{aA}}$ & $3.6 \pm 0.1^{\mathrm{aA}}$ & - & - & $1 \pm 0^{\mathrm{aA}}$ \\
\hline & & 24 & $86.3 \pm 0.6^{\mathrm{dD}}$ & $-3.4 \pm 0.2^{\mathrm{dD}}$ & $25.7 \pm 0.4^{\mathrm{dD}}$ & $23.4 \pm 0.2^{\mathrm{aB}}$ & $30.9 \pm 0.6^{\mathrm{aB}}$ & $5.5 \pm 0 \mathrm{~dB}$ \\
\hline \multirow{6}{*}{ Cs-A } & \multirow{2}{*}{0.5} & 0 & $91.3 \pm 0.9^{\mathrm{aA}}$ & $2.4 \pm 0.4^{\mathrm{aA}}$ & $3.6 \pm 0.1^{\mathrm{aA}}$ & - & - & $1 \pm 0.1^{\mathrm{aA}}$ \\
\hline & & 24 & $88.5 \pm 0.5^{\mathrm{bD}}$ & $-1.4 \pm 0.1^{b C}$ & $11.1 \pm 0.3^{b D}$ & $8.9 \pm 0.1^{\mathrm{cA}}$ & $11.7 \pm 0.3^{\mathrm{cA}}$ & $4 \pm 0.1^{\mathrm{bA}}$ \\
\hline & \multirow{2}{*}{1.0} & 0 & $91.9 \pm 0.7^{\mathrm{aA}}$ & $2.4 \pm 0.3^{\mathrm{aA}}$ & $3.6 \pm 0.6^{\mathrm{aA}}$ & - & - & $1 \pm 0^{\mathrm{aA}}$ \\
\hline & & 24 & $87.2 \pm 0.3^{\mathrm{cE}}$ & $-2.8 \pm 0.2^{\mathrm{cD}}$ & $16.2 \pm 0.5^{\mathrm{cE}}$ & $14.3 \pm 0.6^{\mathrm{bA}}$ & $17.5 \pm 0.6^{\mathrm{bA}}$ & $5.2 \pm 0.1^{\mathrm{cA}}$ \\
\hline & \multirow{2}{*}{2.0} & 0 & $92.2 \pm 0.5^{\mathrm{aA}}$ & $2.4 \pm 0.4^{\mathrm{aA}}$ & $3.7 \pm 0.4^{\mathrm{aA}}$ & - & - & $1.1 \pm 0^{\mathrm{aA}}$ \\
\hline & & 24 & $85.9 \pm 0.4^{\mathrm{dE}}$ & $-3.8 \pm 0.1 \mathrm{dE}$ & $31.6 \pm 0.5^{\mathrm{dE}}$ & $29.2 \pm 0.4^{\mathrm{aA}}$ & $40.6 \pm 0.5^{\mathrm{aA}}$ & $6.2 \pm 0.1 \mathrm{dA}$ \\
\hline
\end{tabular}

Giflerent letters (a-d) in the same films group are significantly different as determined by ANOVA test $(\mathrm{p}<0.05)$.

$\bigoplus$ A $\$$ Berent letters (A-E) indicated significant differences between different films groups at the same heating time $(\mathrm{p}<0.05)$.

44:4Chitosan, A: Arabinose, F: Fructose, G: Glucose, X: Xylose. 
To better study the above-mentioned differences between blank and MR-treated films,

$\Delta \mathrm{E}$ was determined (Table 2). Similarly, $\Delta \mathrm{E}$ shapely increased with the increase of saccharide to Cs mass ratio, especially in the presence of aldopentoses, reaching values of $8.8,19,23$ and 29 for fructose, glucose, xylose and arabinose, respectively $(\mathrm{p}<0.05)$.

Additionally, the BI, reflecting the extent of MR colored products developpement, was assessed. Results in Table 2 show the BI variation of Cs-saccharide MR-conjugated films as a function of saccharide incorporated mass. Indeed, BI increased uniformly with the increase of saccharide content $(\mathrm{p}<0.05)$. For example, values reached more than 11,17 and 40 for $0.5,1.0$ and $2.0 \%(\mathrm{w} / \mathrm{w} \mathrm{Cs}$ ) of arabinose, respectively. The highest BI values were noted in the presence of aldopentoses (xylose and especially arabinose), followed by glucose (aldohexoses). The lowest MR progress, in terms of the lowest BI values, was attained with fructose (ketosis), which is in line with $\Delta \mathrm{E}$ and $\mathrm{b}$ values. Such findings proved that Cs-MR-conjugated films are dark with yellowish color, attributed to the developpement of MR colored products, which could result in an enhancement of their light barrier ability in the visible range.

Furthermore, it was found that the same trend of variation in terms of total color difference and water solubility was followed as a function of MR crosslinking extent (saccharide type and dose). In fact, the MR could be summarized as follows: at the early stage of the MR, conjugates (Schiff base) between the carbonyl group of saccharides and the amine group of Cs are formed, and subsequently cyclizes to develop the Amadori compounds. Thereafter, melanoidins, colored and insoluble polymeric compounds, are formed, allowing the noticeable drop of the Cs-MR-crosslinked films WS and the increase of their BI (Stevenson et al., 2020).

\subsubsection{Light barrier properties assessment}

Light, specifically UV light, is mainly implicated in the oxidation process, through chemical reactions catalyzation, hastening food deterioration, and thereby, its acceptability by 
the consumer (Mahmoudi, Ostadhossein and Simchi, 2016). Therefore, UV and visible light transmission by Cs-MR-conjugated films was assessed in a wavelength range of 200-800 nm and compared with the blank Cs-based film behavior. Results, plotted in Fig. 2, reveal similar trends of variation as function of the MR extent with $\mathrm{b}^{*}, \Delta \mathrm{E}$ and $\mathrm{BI}$, ascribed to the progress of yellow-brown MR end products (melanoidins).

Blank Cs film exhibited a poor barrier property to the light in the UV range as observed through high transmission values at 280 and $350 \mathrm{~nm}$, of $26.97 \%$ and $39.81 \%$, respectively. Nonheated films, added with saccharides, showed no significant variations in the light barrier properties of the in terms of the transmittance values (Fig. 2A-D). In the range of 250-400 nm, Cs-MR-conjugated films spectra revealed particular absorption, in terms of light transmission values that decreased remarkably $(\mathrm{p}<0.05)($ Fig. $2 \mathbf{E}-\mathbf{H})$. This is assumed to be ascribed to the light scattering or the interfering of light track, subsequently to Cs-saccharide crosslinking, hindering thereby light transmittance (Kaya et al., 2018). In fact, oxidation process mainly involves light, specifically UV light, which generates chemical reactions catalyzation, and accelerates the deterioration of food, affecting ultimately the consumer acceptance (Su et al., 2012).

The noteworthy light transmittance reduction at $280 \mathrm{~nm}$, for Cs-MR-treated films reaching an average value of $1 \%$, vs. $30 \%$ for blank Cs-based film, could be attributed to the presence of carbonyl compounds and heterocyclic derivatives (Etxabide et al., 2015). This remarkable UV light barrier increased concomitantly with the increase of saccharide to Cs mass ratio, indicating that Cs-MR-conjugated films effectively prevented UV light. The better barrier behavior, reflected by the lowest light transmittance values, was, as expected, observed with Cs crosslinked with aldopentoses (arabinose and xylose), indicating higher MR products developpement, compared to crosslinking with aldohexoses (glucose) and ketosis (fructose). The lower the transmittance value, the less transparent the films are (Souza et al., 2017). 

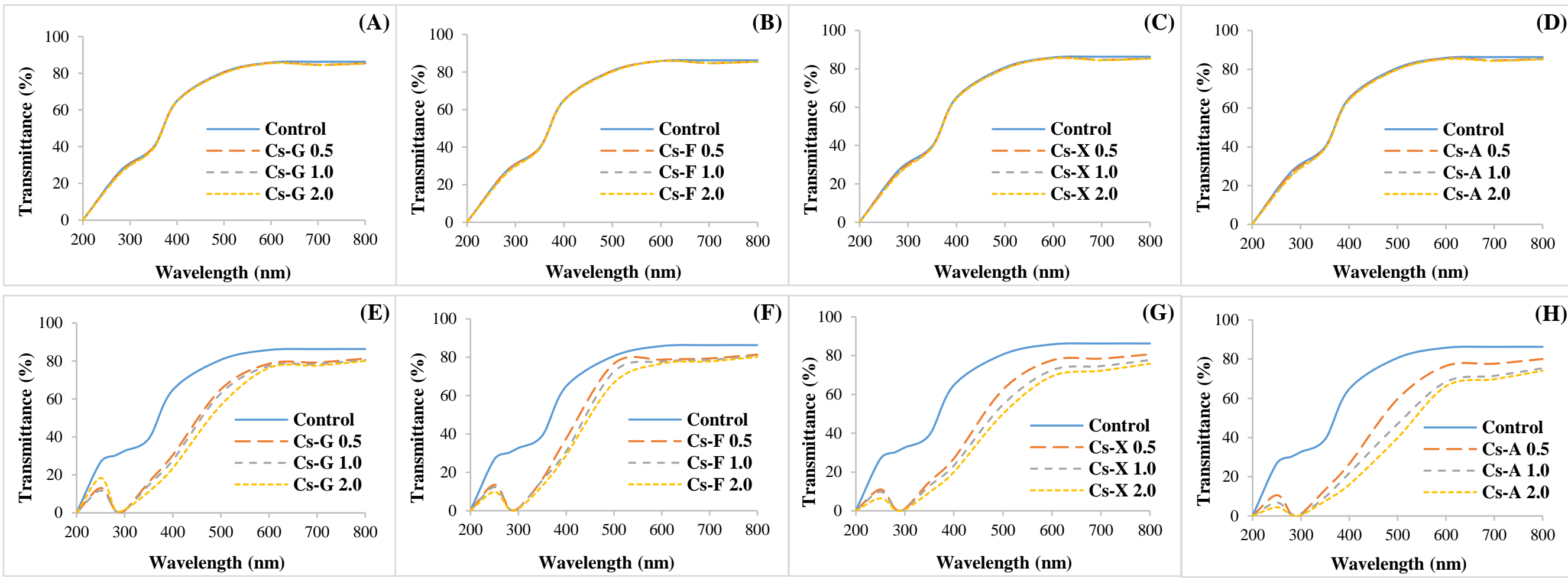

508

$509 \quad$ Figure 2: Transmittance of Cs-based films conjugated with different saccharides, at different mass ratios $(0.5,1.0$ and $2.0 \%$; w/w Cs), through

MR at $90{ }^{\circ} \mathrm{C}$ as a function of time $(0$ and 24 h). Non heated (A-D) and Heated (E-H) Cs-based films. Cs: Chitosan, A: Arabinose, F: Fructose, G:

Glucose, X: Xylose. 

opacity of 0.9 ), the opacity values for the Cs-MR-crosslinked films were significantly higher $(\mathrm{p}<0.05)$, especially with aldopentoses (arabinose and xylose), indicating a lower transparency

515 of the films (Table 2).

Cs-arabinose conjugated film at a mass ratio of $2.0 \%$ (w/w Cs) showed an enhancement in opacity by more than 6-folds, as compared to blank Cs-based film ( $\mathrm{p}<0.05)$. This finding heightens the application of Cs-MR-conjugated films in food preservation (Stevenson et al., 2020; Mahmoudi, et al., 2016).

\subsection{Infrared spectroscopic analysis}

To further confirm the crosslinking in Cs-based films induced by the MR, besides chemical changes of Cs structure due to saccharide addition, FT-IR spectra of non-heated and heated Cs-saccharide films were studied and resulting patterns are shown in Fig. 3. Typical characteristic Cs absorption bands were revealed at around $1589 \mathrm{~cm}^{-1}$ attributed to $\mathrm{N}-\mathrm{H}$ bending in the $\mathrm{NH}-\mathrm{COCH}_{3}$ group (amide II band), $1649 \mathrm{~cm}^{-1}$ characteristic of the amide $\mathrm{I}$ band $(\mathrm{C}=\mathrm{O}$ in the $\mathrm{NHCOCH}_{3}$ group), $1418 \mathrm{~cm}^{-1}$ indicating the $\mathrm{C}-\mathrm{H}$ bending vibrations of $\mathrm{CH}_{2}, 2905 \mathrm{~cm}^{-1}$ ascribed as $\mathrm{CH}_{2}$ and $\mathrm{CH}_{3}$ groups, $894 \mathrm{~cm}^{-1}$ assigned to the absorption peaks of $\beta$ - $(1,4)$ glycosidic bands and at $3423 \mathrm{~cm}^{-1}$ attributed to the stretching vibrations of the $\mathrm{OH}$ and N-H groups (Hamdi et al., 2019b). additionally, for heated blank Cs-based film and non-heated Cs-saccharides films

(Fig. 3A-D), no substantial modification of FT-IR spectra compared to the blank non-heated Cs-based film were detected. In addition, for all studied film samples, a glycerol characteristic band was detected at wavenumber $1046 \mathrm{~cm}^{-1}$, which corresponded to the $\mathrm{OH}$ group vibrations (Vlacha et al., 2016). 


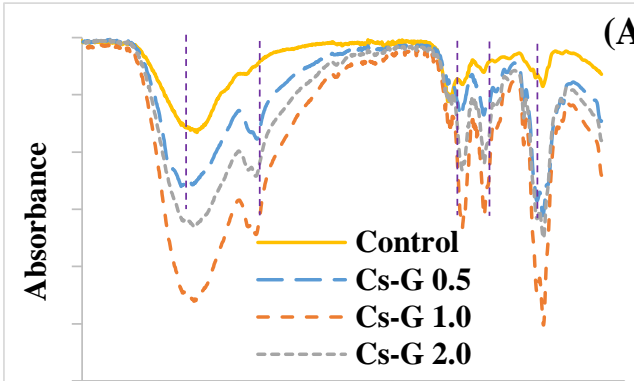

$\begin{array}{llllllll}4000 & 3500 & 3000 & 2500 & 2000 & 1500 & 1000 & 500\end{array}$ Wavenumber $\left(\mathrm{cm}^{-1}\right)$

(A)

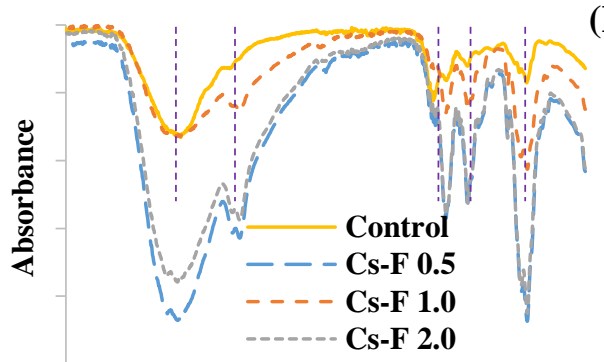

$\begin{array}{llllllll}4000 & 3500 & 3000 & 2500 & 2000 & 1500 & 1000 & 500\end{array}$ Wavenumber $\left(\mathbf{c m}^{-1}\right)$
(B)

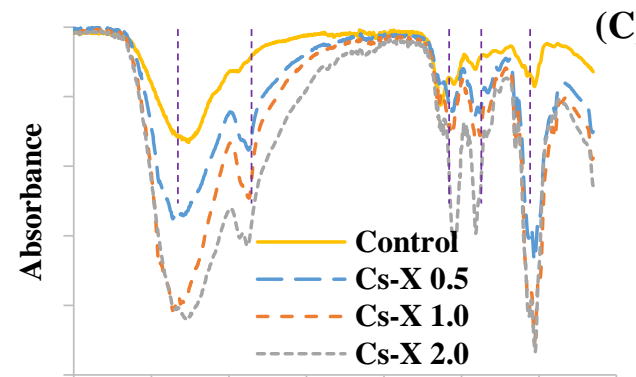

$\begin{array}{llllllll}4000 & 3500 & 3000 & 2500 & 2000 & 1500 & 1000 & 500\end{array}$ Wavenumber $\left(\mathrm{cm}^{-1}\right)$

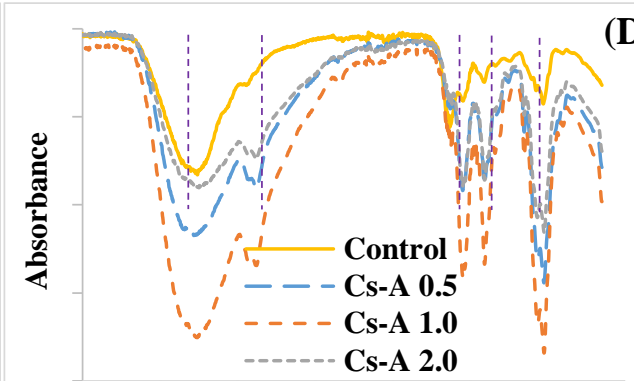

$4000 \quad 3500 \quad 3000 \quad 2500 \quad 2000 \quad 1500 \quad 1000 \quad 500$ Wavenumber $\left(\mathbf{c m}^{-1}\right)$

\section{5}

(E)

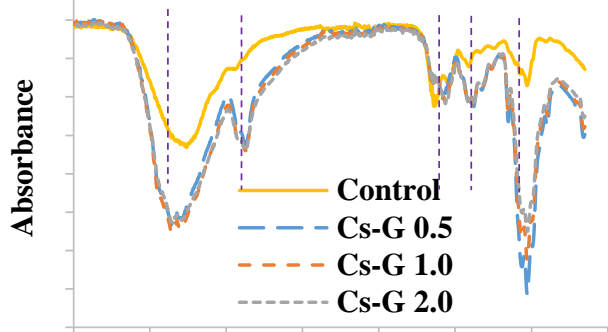

$4000 \quad 3500 \quad 3000 \quad 2500 \quad 2000 \quad 1500 \quad 1000 \quad 500$ Wavenumber $\left(\mathrm{cm}^{-1}\right)$

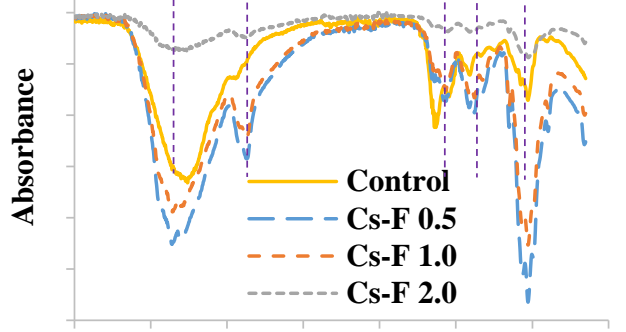

$\begin{array}{llllllll}4000 & 3500 & 3000 & 2500 & 2000 & 1500 & 1000 & 500\end{array}$

Wavenumber $\left(\mathrm{cm}^{-1}\right)$
(F)

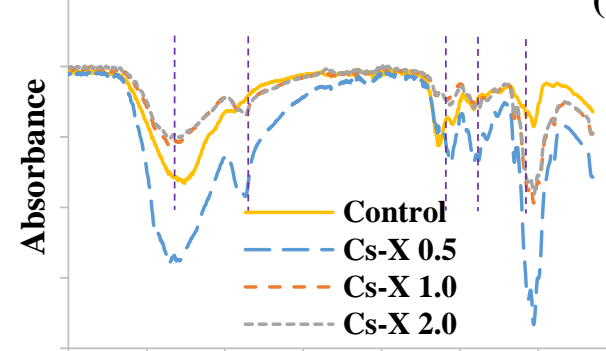

$\begin{array}{llllllll}4000 & 3500 & 3000 & 2500 & 2000 & 1500 & 1000 & 500\end{array}$ Wavenumber $\left(\mathrm{cm}^{-1}\right)$
(G)

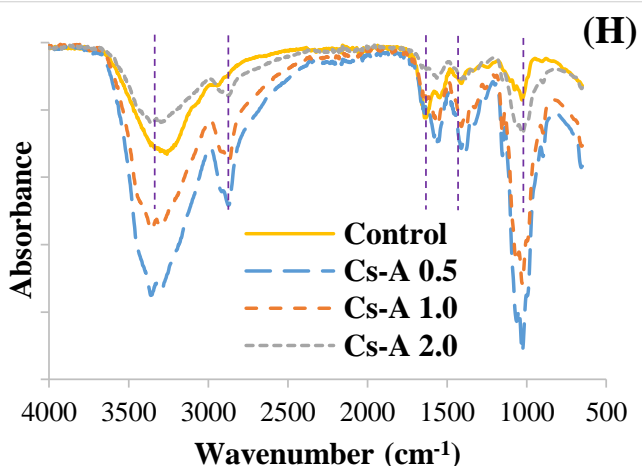

Figure 3: ATR -FTIR spectra of Cs-based films conjugated with different saccharides, at different mass ratios (0.5, 1.0 and 2.0 \%; w/w Cs), through MR at $90{ }^{\circ} \mathrm{C}$ as a function of time (0 and 24 h). Non heated (A-D) and Heated (E-H) Cs-based films. Cs: Chitosan, A: Arabinose, F: Fructose, G: Glucose, X: Xylose. 
The Cs and saccharides' intermolecular interactions were illustrated by the shifts in band

541 positions (Stevenson et al., 2020; Xu et al., 2019; Ahmed and Ikram, 2016). Indeed, after reaction, independently of their type and concentration, saccharides addition to Cs caused significant difference in the resulting spectra (Fig. 3E-H). The absorption peak at wavenumber $1649 \mathrm{~cm}^{-1}$ (Amide I) decreased and shifted to $1607 \mathrm{~cm}^{-1}$ suggesting the formation of Schiff base $(-\mathrm{C}=\mathrm{N})$ between the saccharides reducing termination and the Cs amino groups (Zhong et al., 2019). In brief, the MR conjugation between an aldose sugar and an amino group of Cs stimulated the developpement of $\mathrm{N}$-substituted glycosylamines that arranged to Amadori rearrangement products, the 1 amino-1-desoxy-2-ketoses. Thus, the formation of Schiff base of furfurals involved in aldols, aldimines, ketimes and melanoidins formation (Duconseille, Astruc, Quintana, Meersman and Sante-Lhoutellier, 2015).

Moreover, shifts from $1589 \mathrm{~cm}^{-1}$ (Amide II) to $1544 \mathrm{~cm}^{-1}$, after $24 \mathrm{~h} \mathrm{MR}$ time, were ascribed to the Cs conformation transformations, during the crosslinking reaction between Cs and saccharides. After MR crosslinking, more randomly disposition occurred, increasing, thereby, the molecular disorder (Badano et al., 2019). In fact, the reaction of the carbonyl group of each saccharide with the amino group of $\mathrm{Cs}$, resulted in the elaboration of C-O-C ether linkage, due to -OH condensation. Therefore, overall change in Cs-saccharides glycated system took place and a characteristic adsorption in the wavenumber range of $1098-1021 \mathrm{~cm}^{-1}$ was detected (Du, Huang, Wang and Xiao, 2018).

\subsection{Thermal behavior of Cs-based films as affected by the MR crosslinking}

The thermal stability of Cs-based films crosslinked or not with the MR was assessed by TGA in a temperature range of 25 to $800{ }^{\circ} \mathrm{C}$ (Supplementary Data Fig. S3). The thermal decomposition data in terms of corresponding weight loss $(\Delta \mathrm{w})$, temperature of maximum degradation (Tmax) and final residual mass (R) are reported in Table 3. 
Table 3: Weight loss $(\Delta \mathrm{w})$, temperature of maximum degradation (Tmax), residual mass $(\mathrm{R})$ and glass transition temperature ( $\mathrm{Tg}$ ) of Cs-based films crosslinked with different saccharides of different molar ratios, via the MR at $90{ }^{\circ} \mathrm{C}$.

\begin{tabular}{|c|c|c|c|c|c|c|}
\hline \multicolumn{2}{|c|}{ Film formulations } & \multirow{2}{*}{$\begin{array}{c}\text { MR heating } \\
\text { time (h) } \\
0\end{array}$} & \multirow{2}{*}{$\begin{array}{c}\Delta \mathrm{w}(\%) \\
67.2^{\mathrm{aA}}\end{array}$} & \multirow{2}{*}{$\begin{array}{c}\mathbf{T m a x}\left({ }^{\circ} \mathbf{C}\right) \\
294.3^{\mathrm{aA}}\end{array}$} & \multirow{2}{*}{$\begin{array}{l}\mathbf{R}(\boldsymbol{\%}) \\
25.9^{\mathrm{aA}}\end{array}$} & \multirow{2}{*}{$\begin{array}{l}\mathbf{T g}\left({ }^{\circ} \mathbf{C}\right) \\
162.6^{\mathrm{aA}}\end{array}$} \\
\hline \multirow{2}{*}{\multicolumn{2}{|c|}{ Cs }} & & & & & \\
\hline & & 24 & $66.6^{\mathrm{bA}}$ & $292.8^{\mathrm{bA}}$ & $26.8^{\mathrm{aA}}$ & $169.9^{\mathrm{bA}}$ \\
\hline \multirow{6}{*}{ Cs-G } & \multirow{2}{*}{0.5} & 0 & $67.8^{\mathrm{aB}}$ & $296.7^{\mathrm{aC}}$ & $26^{\mathrm{aA}}$ & $162.4^{\mathrm{aA}}$ \\
\hline & & 24 & $66.8^{\mathrm{bA}}$ & $299.6^{\mathrm{cC}}$ & $30.2^{\mathrm{bB}}$ & $182.6^{\mathrm{cC}}$ \\
\hline & \multirow{2}{*}{1.0} & 0 & $67.1^{\mathrm{aB}}$ & $297.9^{\mathrm{bD}}$ & $26.1^{\mathrm{aA}}$ & $163.2^{\mathrm{bA}}$ \\
\hline & & 24 & $66.3^{\mathrm{bA}}$ & $301.2^{\mathrm{dE}}$ & $30.6^{\mathrm{bB}}$ & $183.1^{\mathrm{dC}}$ \\
\hline & \multirow{2}{*}{2.0} & 0 & $66.4^{\mathrm{bC}}$ & $299.2^{\mathrm{cF}}$ & $25.8^{\mathrm{aA}}$ & $162.9^{\mathrm{aA}}$ \\
\hline & & 24 & $65.9^{\mathrm{cB}}$ & $302^{\mathrm{eF}}$ & $31.4^{\mathrm{cB}}$ & $187.6^{\mathrm{eD}}$ \\
\hline \multirow{6}{*}{ Cs-F } & \multirow{2}{*}{0.5} & 0 & $69^{\mathrm{aA}}$ & $295.6^{\mathrm{aB}}$ & $25.9^{\mathrm{aA}}$ & $162.8^{\mathrm{aA}}$ \\
\hline & & 24 & $66.3^{\mathrm{cA}}$ & $298^{\mathrm{cB}}$ & $30.1^{\mathrm{bB}}$ & $179.1^{\mathrm{bB}}$ \\
\hline & \multirow{2}{*}{1.0} & 0 & $67.1^{\mathrm{bB}}$ & $297.4^{\mathrm{bD}}$ & $26.1^{\mathrm{aA}}$ & $162.5^{\mathrm{aA}}$ \\
\hline & & 24 & $65.8^{\mathrm{dB}}$ & $298.9^{\mathrm{cdB}}$ & $30.6^{\mathrm{bB}}$ & $181.1^{\mathrm{cB}}$ \\
\hline & \multirow{2}{*}{2.0} & 0 & $66.2^{\mathrm{cC}}$ & $298.8^{\mathrm{cdE}}$ & $26.1^{\mathrm{aA}}$ & $162.1^{\mathrm{aA}}$ \\
\hline & & 24 & $65.6^{\mathrm{dB}}$ & $300.4^{\mathrm{dD}}$ & $31.2^{\mathrm{bB}}$ & $184.6^{\mathrm{dB}}$ \\
\hline \multirow{6}{*}{ Cs-X } & \multirow{2}{*}{0.5} & 0 & $67.4^{\mathrm{aB}}$ & $298^{\mathrm{aE}}$ & $26.1^{\mathrm{aA}}$ & $162.3^{\mathrm{aA}}$ \\
\hline & & 24 & $66.3^{\mathrm{bA}}$ & $299.6^{\mathrm{bcC}}$ & $30.4^{\mathrm{bB}}$ & $183.4^{\mathrm{bD}}$ \\
\hline & \multirow{2}{*}{1.0} & 0 & $67.4^{\mathrm{aB}}$ & $299.7^{\mathrm{bcF}}$ & $26^{\mathrm{aA}}$ & $162.9^{\mathrm{aA}}$ \\
\hline & & 24 & $66.3^{\mathrm{bA}}$ & $301.2^{\mathrm{dE}}$ & $31.5^{\mathrm{cC}}$ & $186.7^{\mathrm{cE}}$ \\
\hline & \multirow{2}{*}{2.0} & 0 & $66.5^{\mathrm{bC}}$ & $300.4^{\mathrm{cG}}$ & $26.1^{\mathrm{aA}}$ & $162.7^{\mathrm{aA}}$ \\
\hline & & 24 & $65.1^{\mathrm{cB}}$ & $302.8^{\mathrm{eF}}$ & $32.2^{\mathrm{dC}}$ & $188.4^{\mathrm{dC}}$ \\
\hline \multirow{6}{*}{ Cs-A } & \multirow{2}{*}{0.5} & 0 & $67.6^{\mathrm{aB}}$ & $299.3^{\mathrm{aF}}$ & $25.9^{\mathrm{aA}}$ & $162.6^{\mathrm{aA}}$ \\
\hline & & 24 & $66.5^{\mathrm{bA}}$ & $300.4^{\mathrm{bD}}$ & $30.6^{\mathrm{bB}}$ & $183.9^{\mathrm{cD}}$ \\
\hline & \multirow{2}{*}{1.0} & 0 & $66.4^{\mathrm{bC}}$ & $301.2^{\mathrm{cH}}$ & $26.1^{\mathrm{aA}}$ & $163.2^{\mathrm{bB}}$ \\
\hline & & 24 & $65.7^{\mathrm{cB}}$ & $302.1^{\mathrm{dE}}$ & $31.9^{\mathrm{cC}}$ & $185.8^{\mathrm{dD}}$ \\
\hline & \multirow{2}{*}{2.0} & 0 & $64.9^{\mathrm{dD}}$ & $301.9^{\mathrm{cdH}}$ & $26.2^{\mathrm{aA}}$ & $163.1^{\mathrm{bB}}$ \\
\hline & & 24 & $63.8^{\mathrm{eC}}$ & $303.6^{\mathrm{eG}}$ & $32.8^{\mathrm{dC}}$ & $193.1^{\mathrm{eE}}$ \\
\hline
\end{tabular}



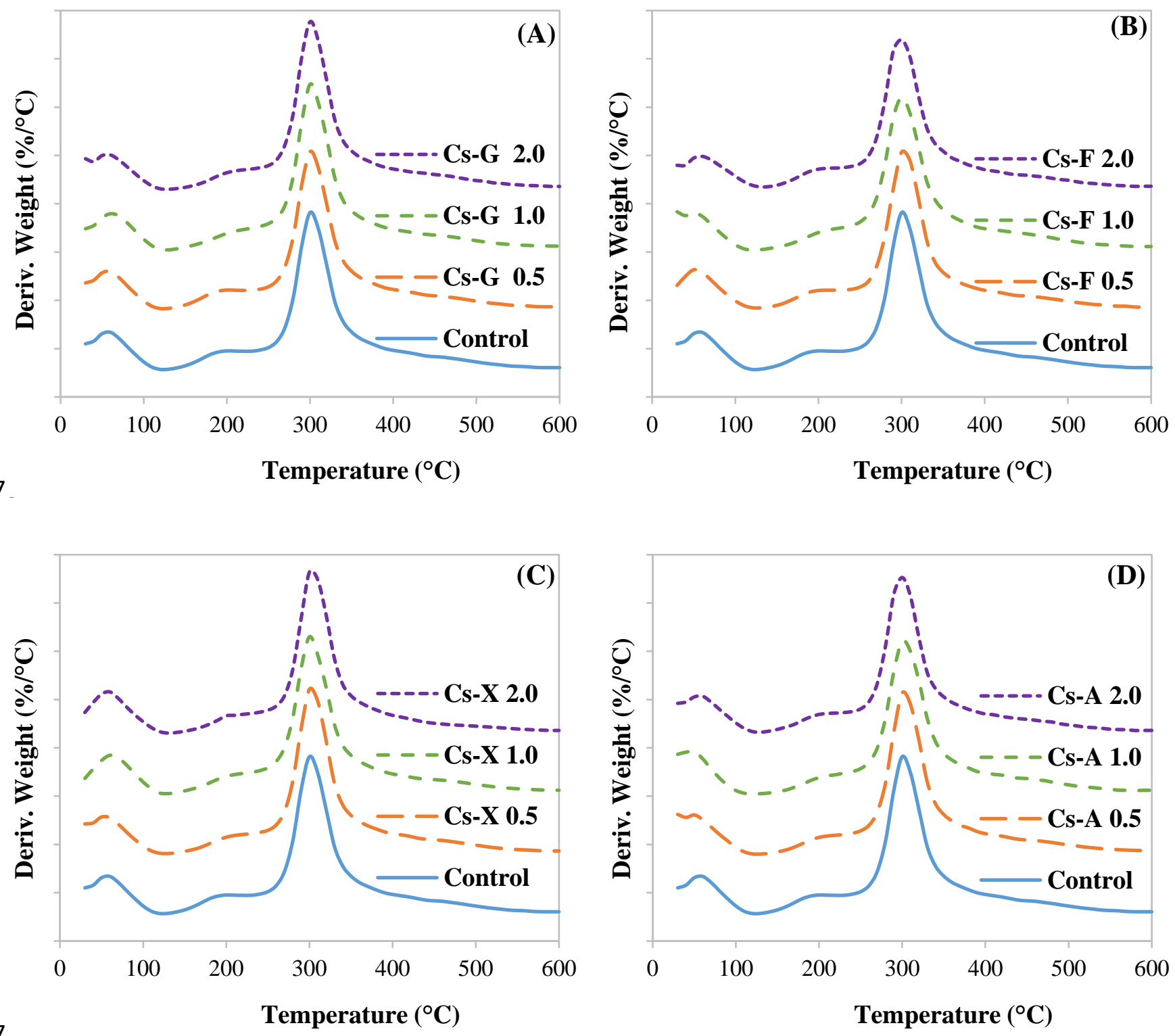

Figure 4: DTG profiles of Cs-based films conjugated with different saccharides, at different mass ratios $(0.5,1.0$ and $2.0 \%$; w/w Cs $)$, through $\mathrm{MR}$ at $90{ }^{\circ} \mathrm{C}$ for $24 \mathrm{~h}$. Cs: Chitosan, A: Arabinose, F: Fructose, G: Glucose, X: Xylose. of the overall films exhibited a similar weight loss process in the temperature range of 25 to $800{ }^{\circ} \mathrm{C}$, characterized by two distinguishable major phases (Fig. 4), characteristic of chitosanbased biomaterials thermal decomposition. The first stage of transformation is related to the loss of free and bound water (below $100{ }^{\circ} \mathrm{C}$ ), which tended to decrease for Cs-MR-crosslinked films, in line with the WC findings (Fig. 1A), proving that MR-treated films $\left(90{ }^{\circ} \mathrm{C}, 24 \mathrm{~h}\right.$ ) 
exhibited lower WC than the non-heated films. The second stage of weight loss, corresponding to the major $\Delta \mathrm{w}$ around 63 to $67 \%$, displayed the degradation or the decomposition of Cs chains at approximately $292-303{ }^{\circ} \mathrm{C}$.

Results in Table 3 display that the incorporation of saccharides in the Cs film-forming matrix without heat treatment did not affect significantly the $\Delta \mathrm{w}$ of films, at around $67 \%$. Nevertheless, the lowest $\Delta \mathrm{w}$ value was around $63 \%$ for Cs-arabinose crosslinked film, at a mass ratio of $2.0 \%(\mathrm{w} / \mathrm{w} \mathrm{Cs})$.

Regarding Tmax values, no significant changes were noted for the non-heated films ( $>0.05$ ). However, when comparing to the blank heated Cs-based film $\left(292^{\circ} \mathrm{C}\right)$, saccharides incorporation increased Tmax values of Cs-MR-conjugated films in a saccharide dose dependent manner $(\mathrm{p}<0.05)$, to reach by $300.4{ }^{\circ} \mathrm{C}, 302{ }^{\circ} \mathrm{C}, 302.8{ }^{\circ} \mathrm{C}$ and $303.6{ }^{\circ} \mathrm{C}$ for $\mathrm{Cs}-$ fructose, Cs-glucose, Cs-xylose and Cs-arabinose crosslinked films, at a saccharide to Cs mass ratio of $2.0 \%$ (w/w Cs), respectively (Table 3).

Similar trends were observed for the $\mathrm{R}$ values, which raised concomitantly with the saccharide concentration, attaining a maximum $\mathrm{R}$ value of $32 \%$ with $2.0 \%$ (w/w Cs) of aldopentoses (arabinose). This thermal resistance behavior could be correlated to the MR crosslinking extent, through creation of new bonds between Cs macromolecular chains, inducing their thermal stability. Additionally, MR products could interact with the Cs polymeric matrix, allowing the stabilization of film network, thus the increase in the observed thermal stability for Cs-MR-treated films (Kchaou et al., 2018; Su et al., 2012).

The thermal properties of Cs-MR-conjugated films were further assessed by the DSC analysis in order to determine the glass transition temperature (Tg) and obtained results are shown in Table 3. In the same line with TGA outcomes, a clear increase in all films Tg values was displayed with increasing the saccharide content, which could be ascribed either to WC decrease, or to crosslinking phenomenon. Indeed, the Tg increased from $169{ }^{\circ} \mathrm{C}$ for blank Cs- 
based film to $184,187,188$ and $193{ }^{\circ} \mathrm{C}$ for Cs-fructose, Cs-glucose, Cs-xylose and Cs-arabinose crosslinked films, at a saccharide to Cs mass ratio of $2.0 \%$ (w/w Cs), respectively $(\mathrm{p}<0.05$ ). Even at low saccharide content of $0.5 \%$ (w/w Cs), improved Tg values of 179, 182, 183.4 and 183.9 ${ }^{\circ} \mathrm{C}$ for Cs-fructose, Cs-glucose, Cs-xylose and Cs-arabinose crosslinked films, respectively $(\mathrm{p}<0.05)$. Advantageously, DSC thermograms (Supplementary Data Fig. S4) reveal a single $\mathrm{Tg}$ for all the tested films indicating a good compatibility between tested saccharides and Cs, in these conditions (Hamdi et al., 2019a).

Consequently, the $\mathrm{Tg}$ as well as the degradation temperature enhancement approved that MR, through its crosslinking effect between the amino group of the glucosamine unit and the carbonyl of saccharide, modified the Cs polymeric structure, elaborating a more thermally stable matrix. This phenomenon is more pronounced in the presence of pentoses (arabinose and xylose), with less carbons in their macromolecular chain, showing higher crosslinking extent, resulting in higher degradation temperatures values, compared to the hexoses (fructose and glucose), with more carbons. Particularly, aldoses (arabinose, xylose and glucose), with a carbonyl group located at one end of the carbon chain, were more reactive than ketoses (fructose), with a carbonyl group situated inside the carbon chain. This enhanced and interesting thermal behavior of Cs-MR-conjugated films could be promising for upgraded mechanical properties.

\subsection{Mechanical properties changes of Cs-based MR-treated films}

To have information about their flexibility and stretchability, mechanical properties of Cs-saccharides crosslinked through the MR, in terms of TS and EAB were measured and compared to Cs-based film (Table 1). Indeed, used or predicted materials for food packaging need to uphold their integrity and effectively resist to plenty types of stress occurring during distribution, treatment and storage (Kaya et al., 2018). Based on the tensile stress vs. strain curves, no significant effect of the addition of saccharides without heating, i.e. no MR occurred, 
on the control films TS and EAB values was observed ( $p>0.05)$. In addition, heat treatment (90 ${ }^{\circ} \mathrm{C}$ for $24 \mathrm{~h}$ ) did not affect the mechanical parameters of Cs-blank film (p>0.05).

In counterpart, subsequently to the MR crosslinking, a significant improvement of Cssaccharides MR crosslinked films mechanical behavior was detected, considering the resultant increase of TS and EAB values, in a saccharide dose-dependent manner $(\mathrm{p}<0.05)$. In fact, TS values enhanced by $1.17,1.28$ and 1.45 -folds, for $0.5,1.0$ and $2.0 \%$ (w/w Cs) of arabinose, compared to the blank Cs-based film (18.7 MPa). Equally, EAB increased from $29.8 \%$ for blank Cs-based film to $32.1 \%$ and $37.1 \%$ for $0.5 \%$ and $1.0 \%$ (w/w Cs) Cs-arabinose crosslinked films, respectively (Table 1). The same trend was noted for the other tested saccharides, but in the following order of reactivity: arabinose $>$ xylose $>$ glucose $>$ fructose. The lowest TS value of 22.8 MPa and EAB of $32.9 \%$ were exhibited by the $2.0 \%$ (w/w Cs) Cs-fructose MR crosslinked film.

These advantageous mechanical properties of Cs-saccharides MR crosslinked films, particularly through conjugation with aldopentoses, among which arabinose and xylose, is in line with thermal (DSC and TGA) outcomes, proving a positive correlation between TS and Tg of films. Actually, the changes of $\mathrm{Tg}$ is not only a current indicator of additives and macromolecules compatibility in the film polymeric network, but it permits likewise to enlighten the polymeric material mechanical resistance parameters (Mujeeb Rahman, Abdul Mujeeb, Muraleedharan and Thomas, 2018). This particular behavior (more reactivity with aldopentoses than ketoses and hexoses) corroborated, as well, with the above described MC results, attributed to MR crosslinking, besides the saccharides plasticizing action (Kamboj et al., 2015).

\subsection{Effect of the MR crosslinking on the microstructure of Cs-based films}

The Cs-based films treated with the MR were analyzed for transverse sections after gold coating, to qualitatively visualize their microstructure (homogeneity, layer, voids, etc.) and to 
identify microstructural modifications, allowing a better understanding of polymers filmforming behavior.

Based on the overall above reported results, the Cs-saccharides films at a concentration of $2.0 \%(\mathrm{w} / \mathrm{w} \mathrm{Cs})$ crosslinked through the MR $\left(90{ }^{\circ} \mathrm{C}\right.$ for $\left.24 \mathrm{~h}\right)$ were selected for the SEM analysis, and compared with the non-added Cs-based film (Fig. 5).

Cs

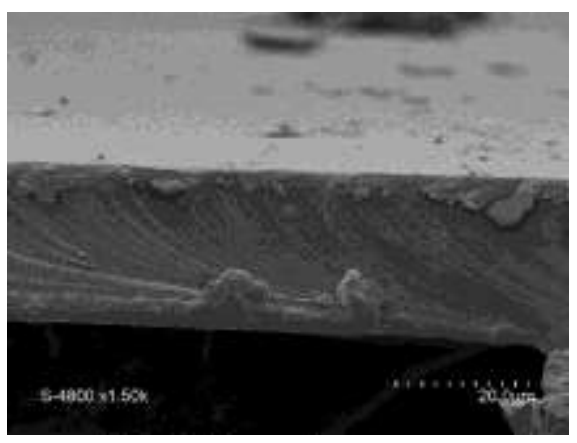

Cs-G

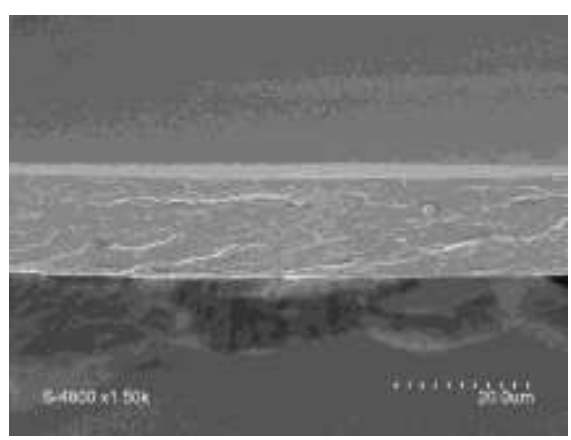

Cs-X

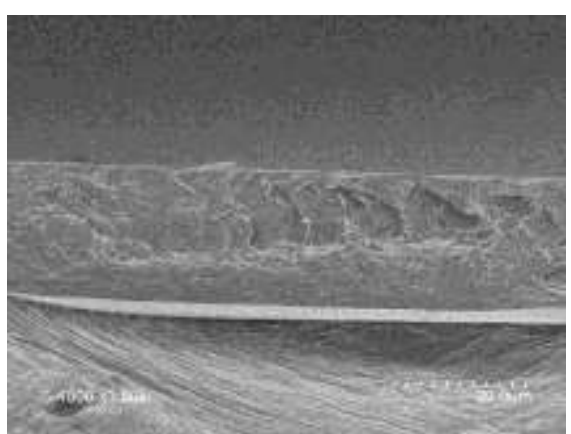

Cs-F

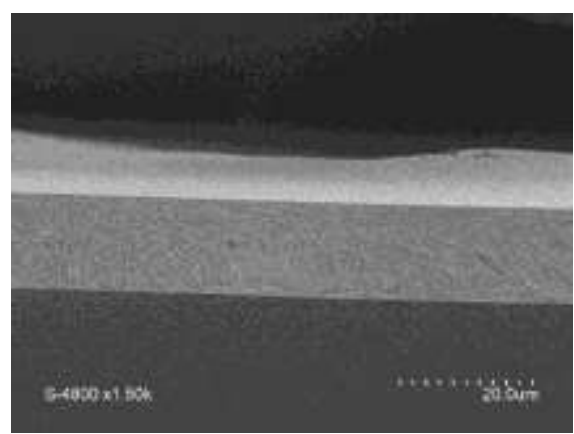

Cs-A

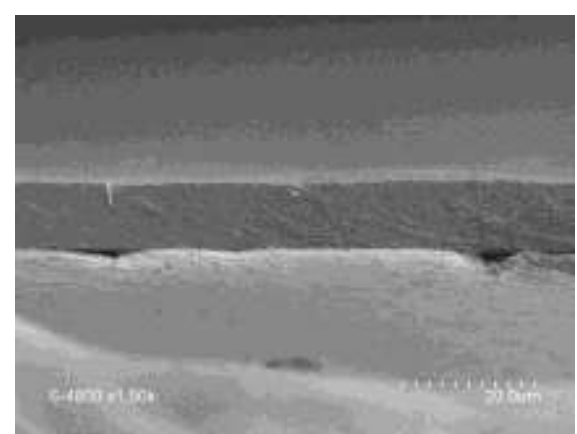

Figure 5: SEM cross-section $(1.50 \mathrm{kV}, 20 \mu \mathrm{m}$ and $25.0 \mathrm{kV})$ of Cs-based films conjugated with different saccharides, at different mass ratios $(0.5,1.0$ and $2.0 \%$; w/w Cs $)$, through $\mathrm{MR}$ at $90{ }^{\circ} \mathrm{C}$ for $24 \mathrm{~h}$. Cs: Chitosan, A: Arabinose, F: Fructose, G: Glucose, X: Xylose. 
675

676

677

678

679

680

681

682

683

684

685

686

687

688

689

690

691

692

693

694

695

696

697

continuous, homogeneous phase in Cs-based film could be observed, without any evidence of irregularities (air bubbles, pores, cracks or droplets) or phase separation (Hamdi et al., 2019a).

The incorporation of saccharides into Cs network combined with heat treatment at $90{ }^{\circ} \mathrm{C}$ for $24 \mathrm{~h}$ distinguishably changed the cross-section structure of MR-treated films. It was possible to confirm more homogeneity and density were detected with higher crosslinking rates. Otherwise, aldopentoses (xylose and particularly arabinose) were more reactive toward the MR than ketosis (fructose) and aldohexoses (glucose), allowing higher rates of crosslinking, resulting in such peculiar microstructural arrangements. These film-forming ultra-structures are in agreement with FT-IR analysis, confirming the above observed results, in terms of thermal, mechanical and barrier behaviors (Mujeeb Rahman et al., 2018; Rubentheren et al., 2016).

\subsection{Antioxidant activities of Cs-based MR crosslinked films}

The global antioxidative mechanism could be ascribed to the cooperative effects of different systems, such as metal chelation and radicals scavenging (Zhang, Chen, Zhang, Ma and $\mathrm{Xu}, 2013)$. Therefore, to investigate the antioxidativity of the Cs-based MR crosslinked films, differents in vitro antioxidant tests were implemented: DPPH radical scavenging (free radicals quenching), reducing power (iron reduction ability) and metal chelating assays (Fig. 6). Data in the present work reveal that for all antioxidant systems investigated, values were remarkably higher $(\mathrm{p}<0.05)$ in Cs-based MR crosslinked films than in the blank Cs-based film. Indeed, blank Cs-based film exhibited weak reducing power of $\mathrm{OD}_{700}=0,165 \pm 0009$ (Fig. 6A), whereas, good antioxidant activities of $74.1 \pm 0.58 \%$ and $75.27 \pm 1.91 \%$ were displayed for DPPH radical scavenging (Fig. 6B) and metal chelating (Fig. 6C). The availability of -OH and $-\mathrm{NH}_{2}$ groups throughout the polymer matrix reflected the antioxidant ability of Cs, thus Csbased films antioxidant patterns (Badano et al., 2019; Hamdi et al., 2019a). 
Subsequently to the MR crosslinking and the incorporation of saccharides into the film-

699

700

701

702

703

704

705

706

707

708

709

710

711

712

713

714

715

716

717 forming matrix, the antioxidant activity was enhanced and values increased and was directly correlated to the amount of added saccharide. Interestingly, the reducing power antioxidant activity of Cs-based MR treated film with $0.5 \%$ and $2.0 \%$ of arabinose (w/w Cs) increased by more than 13- and 16-folds, respectively, compared to the blank Cs-based film (Fig. 6A). Moreover, the highest values of inhibition of $100 \%$ for DPPH radical scavenging (Fig. 6B) and metal chelating (Fig. 6C) were exhibited, at the same concentration of arabinose. Several mechanisms could be implicated in the antioxidant activity of Cs-based MR-treated films. Indeed, the reducing power could be attributed either to MR products formed in the primary phase of the MR during thermolysis of Amadori compounds, or to MR final stage heterocyclic compounds (Chen et al., 2019). Furthermore, the marked increase in the scavenging activity of MR-treated films could be associated with the reduction of the number of reactive amino groups produced by the MR, otherwise, the intermediates and the final brown polymer (melanoidins) could behave as hydrogen donors (Akar, Küçük and Doğan, 2017; Zhang, Shen, Zhu and Xu, 2015).

In line with above-mentioned in the FT-IR analysis and perceived by SEM, these findings could explain the fact that the extent of the MR, as reflected by higher in vitro antioxidant activities, was influenced by the type of saccharides $(\mathrm{p}<0.05)$. Pentoses (arabinose and xylose), with less carbons in their macromolecular chain, showed higher reducing power (Fig. 6A), radical scavenging (Fig. 6B) and metal chelating activities (Fig. 6C), compared to the hexoses (fructose and glucose), with more carbons. More particularly, aldoses (arabinose, xylose and glucose), with a carbonyl group located at one end of the carbon chain, were more reactive than ketosis (fructose), with a carbonyl group situated inside the carbon chain, which could be the result of higher covalent crosslinking extent. 


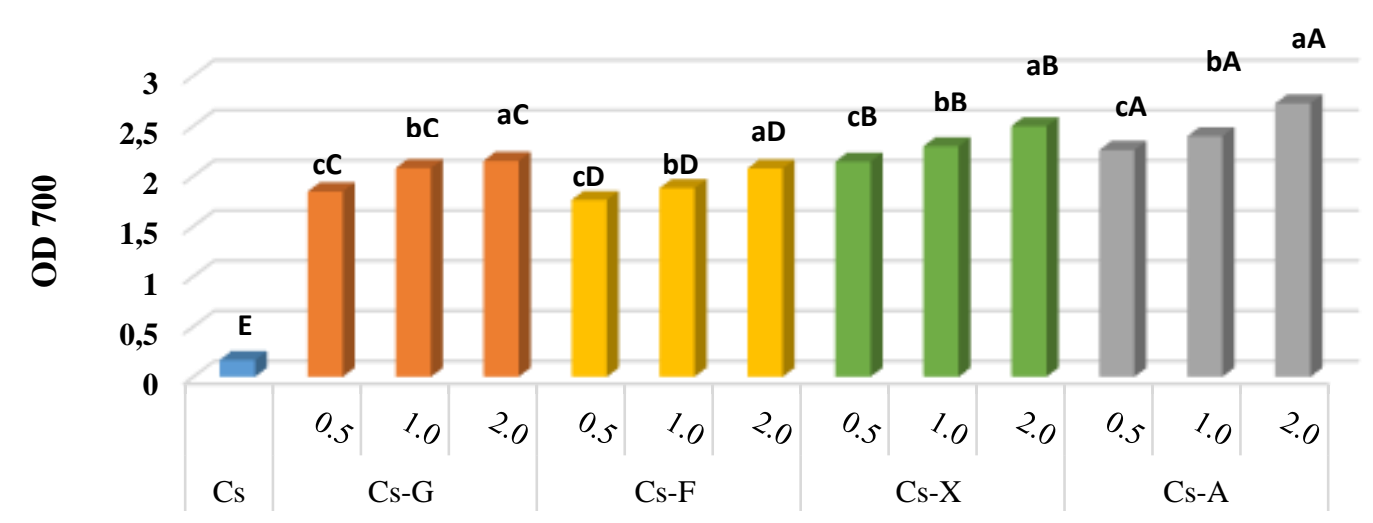

Film formulations

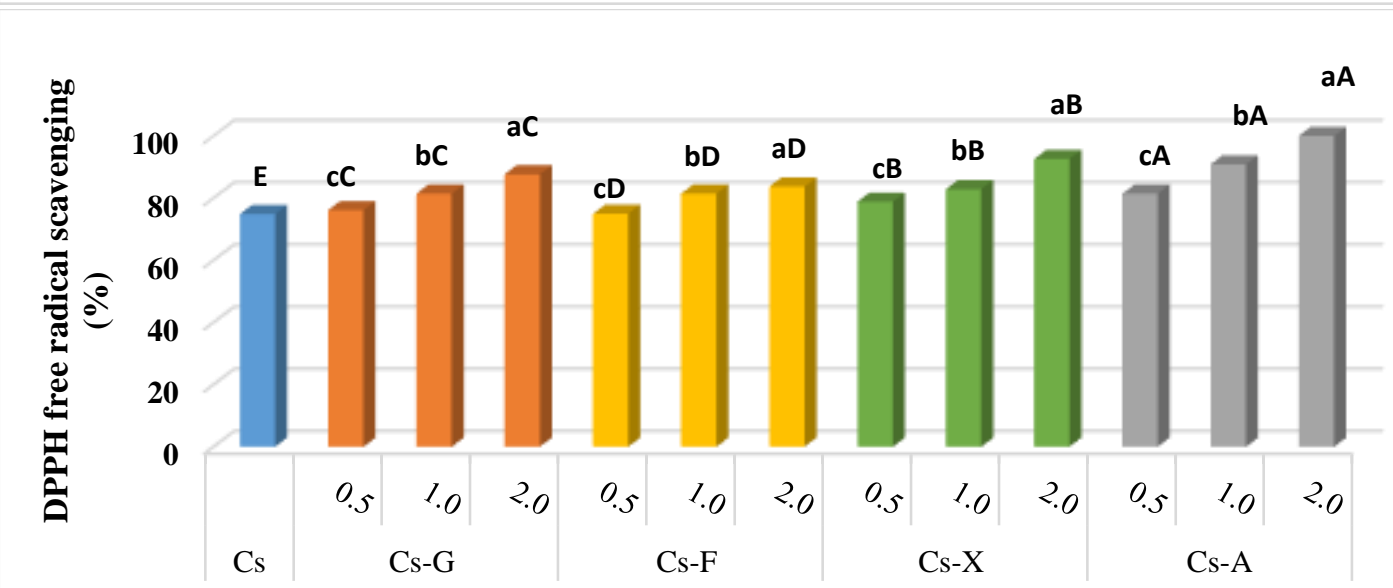

Film formulations

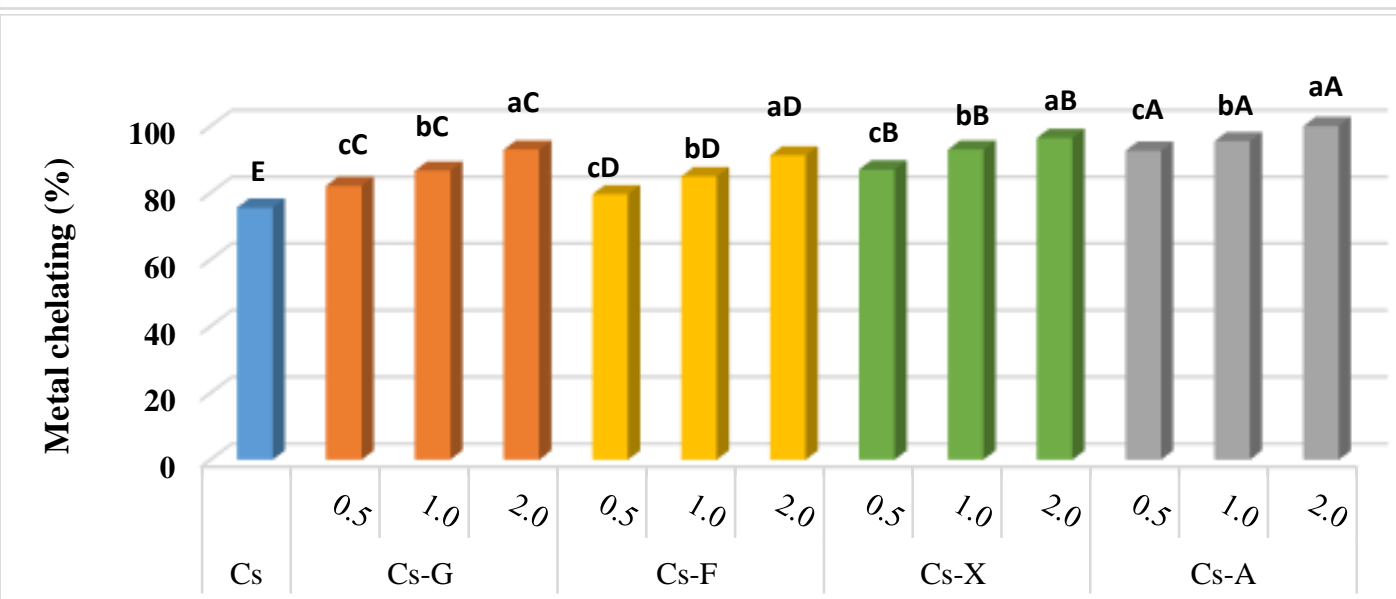

(C)

Film formulations

Figure 6: Antioxidant activities of Cs-based films conjugated with different saccharides, at different mass ratios $\left(0.5,1.0\right.$ and $2.0 \%$; w/w Cs), through $\mathrm{MR}$ at $90{ }^{\circ} \mathrm{C}$ for $24 \mathrm{~h}$, based on the reducing power (A), DPPH free radical scavenging $(\mathbf{B})$ and metal chelation $(\mathbf{C})$ in vitro tests. Cs: Chitosan, A: Arabinose, F: Fructose, G: Glucose, X: Xylose. Different letters ${ }^{(a-c)}$ in the same films group are significantly different as determined by ANOVA test $(\mathrm{p}<0.05)$. Different letters ${ }^{(\mathbf{A}-\mathbf{D})}$ indicated significant differences between different films groups $(\mathrm{p}<0.05)$. 


\section{Conclusion}

In the present work, different types of saccharides were incorporated at different mass ratios into chitosan film forming solution. Maillard reaction crosslinking was induced by films heating at $90{ }^{\circ} \mathrm{C}$ during $24 \mathrm{~h}$. Advantageously, Maillard reaction increased water barrier and resistance of resulted films, as reflected by water solubility, water contact angle and water vapor permeability, in a saccharide type and dose-dependent manner. Treated films crosslinked with aldopentoses were, additionally, less transparent with enhanced light barrier than ketosestreated films. Moreover, Maillard reaction allowed an improvement of the thermal resistance (in terms of glass transition and degradation temperatures) and mechanical behavior, compared to blank non-treated film. Furthermore, Maillard reactions could be considered as an alternative tool to develop chitosan-based films with improved antioxidativity that could then be used as active packaging against foods oxidation, especially using aldopentoses as crosslinkers. The subsequent application of the prepared films in the packaging of food samples, such as oil, fish fillet, etc., is of great interest to concretely confirm their effectiveness.

\section{Acknowledgements}

The present work was funded by the Ministry of Higher Education and Scientific Research, Tunisia. The authors gratefully acknowledge Dr. Christophe CHARMETTE for his helpful aid regarding the water vapor permeability measurements and Dr. Thierry THAMI for water contact angles analyses.

\section{References}

Ahmed, S., Ikram, S. (2016). Chitosan and gelatin based biodegradable packaging films with UV-light protection. Journal of Photochemistry and Photobiology B: Biology, 163, 115124.

Akar, Z., Küçük, M., Doğan, H. (2017). A new colorimetric DPPH• scavenging activity method with no need for a spectrophotometer applied on synthetic and natural antioxidants and medicinal herbs. Journal of Enzyme Inhibition and Medicinal Chemistry, 32, 640-647. 
Akyuz, L., Kaya, M., Koc, B., Mujtaba, M., Ilk, S., Labidi, J., Salaberria, A.M., Cakmak, Y.S., Yildiz, A. (2017). Diatomite as a novel composite ingredient for chitosan film with enhanced physicochemical properties. International Journal of Biological Macromolecules, 105, 1401-1411.

Al Jahwari, F., Pervez, T. (2019). The potential of environmental-friendly biopolymers as an alternative to conventional petroleum-based polymers. Reference Module in Materials Science and Materials Engineering https://doi.org/10.1016/B978-0-12-803581-8.11295$\underline{0}$

Assadpour, E., Jafari, S.M. (2019). Chapter 3 - Nanoencapsulation: Techniques and Developments for Food Applications. In: Rubio, A.M., Sanz, M.M., Rovira, M.J.F., Gómez-Mascaraque, L.G. (Eds.), Nanomaterials for Food Applications-Micro and Nano Technologies (pp. 35-61). Elsevier Inc.

Badano, J.A., Braber, N.V., Rossi, Y., Diaz Vergara, L., Bohl, L., Porporatto, C., Falcone, R.D., Montenegro, M. (2019). Physicochemical, in vitro antioxidant and cytotoxic properties of water-soluble chitosan-lactose derivatives. Carbohydrate Polymers, 224, 115158.

Bersuder, P., Hole, M., Smith, G. (1998). Antioxidants from a heated histidine-glucose model system. I: Investigation of the antioxidant role of histidine and isolation of antioxidants by high-performance liquid chromatography. Journal of the American Oil Chemists' Society, 75, 181-187.

Cai, L., Li, D., Dong, Z., Cao, A., Lin, H., Li, J. (2016). Change regularity of the characteristics of Maillard reaction products derived from xylose and Chinese shrimp waste hydrolysates. LWT - Food Science and Technology, 65, 908-916.

Chen, K., Yang, X., Huang, Z., Jia, S., Zhang, Y., Shi, J., Hong, H., Feng, L., Liu, Y. (2019). Modification of gelatin hydrolysates from grass carp (Ctenopharyngodon idellus) scales by Maillard reaction: Antioxidant activity and volatile compounds. Food Chemistry, 295, 569-578.

Debeaufort, F., Martin-Polo, M., Voilley, A. (1993). Polarity homogeneity and structure affect water vapor permeability of model edible films. Journal of Food Science, 58, 426-429.

Decker, E.A., Welch, B. (1990). Role of ferritin as a lipid oxidation catalyst in muscle food. Journal of Agricultural and Food Chemistry, 38, 674-677.

Du, Y.L., Huang, G.Q., Wang, H.O., Xiao, J.X. (2018). Effect of high coacervation temperature on the physicochemical properties of resultant microcapsules through induction of Maillard reaction between soybean protein isolate and chitosan. Journal of Food Engineering, 234, 91-97.

Duconseille, A., Astruc, T., Quintana, N., Meersman, F., Sante-Lhoutellier, V. (2015). Gelatin structure and composition linked to hard capsule dissolution: A review. Food Hydrocolloids, 43, 360-376.

Etxabide, A., Urdanpilleta, M., Guerrero, P., de la Caba, K. (2015). Effects of crosslinking in nanostructure and physicochemical properties of fish gelatins for bio-applications. Reactive and Functional Polymers, 94, 55-62.

Fernandez-de Castro, L., Mengíbar M., Sanchez, A., Arroyo, L., Villaran, M.C., Díaz de Apodaca, E., Heras, A. (2016). Films of chitosan and chitosan-oligosaccharide neutralized and thermally treated: Effects on its antibacterial and other activities. LWT Food Science and Technology, 73, 368-374.

Galiano, F., Briceño, K., Marino, T., Molino, A., Christensen, K.V., Figoli, A. (2018). Advances in biopolymer-based membrane preparation and applications. Journal of Membrane Science, 564, 562-586.

Gennadios, A., Handa, A., Froning, G.W., Weller, C.L., Hanna, M.A. (1998). Physical properties of egg white-dialdehyde starch films. Journal of Agricultural and Food Chemistry, 46, 1297-1302. 
Gullon, B., Montenegro, M.I., Ruiz-Matute, A.I., Cardelle-Cobas, A., Corzo, N., Pintado, M.E. (2016). Synthesis, optimization and structural characterization of a chitosan-glucose derivative obtained by the Maillard reaction. Carbohydrate Polymers, 137, 382-389.

Hamdi, M., Hajji, S., Affes, S., Taktak, W., Maâlej, H., Nasri, M., Nasri, R. (2018). Development of a controlled bioconversion process for the recovery of chitosan from blue crab (Portunus segnis) exoskeleton. Food Hydrocolloids, 77, 534-548.

Hamdi, M., Nasri, R., Li, S., Nasri, M. (2019a). Bioactive composite films with chitosan and carotenoproteins extract from blue crab shells: Biological potential and structural, thermal, and mechanical characterization. Food Hydrocolloids, 89, 802-812.

Hamdi, M., Nasri, R., Hajji, S., Nigen, M., Li, S., Nasri, M. (2019b). Acetylation degree, a key parameter modulating chitosan rheological, thermal and film-forming properties. Food Hydrocolloids, 87, 48-60.

Hazaveh, P., Mohammadi Nafchi, A., Abbaspour, H. (2015). The effects of sugars on moisture sorption isotherm and functional properties of cold-water fish gelatin films. International Journal of Biological Macromolecules, 79, 370-376.

Jiang, S., Zhang, X., Ma, Y., Tuo, Y., Qian, F., Fu, W., Mu, G. (2016). Characterization of whey protein-carboxymethylated chitosan composite films with and without transglutaminase treatment. Carbohydrate Polymers, 153, 153-159.

Joye, I.J. (2019). Cereal biopolymers for nano- and microtechnology: A myriad of opportunities for novel (functional) food applications. Trends in Food Science \& Technology, 83, 1-11.

Kamboj, S., Singh, K., Tiwary, A.K., Rana, V. (2015). Optimization of microwave assisted Maillard reaction to fabricate and evaluate corn fiber gum-chitosan IPN films. Food Hydrocolloids, 44, 260-276.

Kaya, M., Ravikumar, P., Ilk, S., Mujtaba, M., Akyuz, L., Labidi, J., Salaberria, A.M., Cakmak, Y.S., Erkul, S.K. (2018). Production and characterization of chitosan based edible films from Berberis crataegina's fruit extract and seed oil. Innovative Food Science \& Emerging Technologies, 45, 287-297.

Kchaou, H., Benbettaïeb, N., Jridi, M., Abdelhedi, O., Karbowiak, T., Brachais, C.H., Léonard, M.L., Debeaufort, F., Nasri, M. (2018). Enhancement of structural, functional and antioxidant properties of fish gelatin films using Maillard reactions. Food Hydrocolloids, 83, 326-339.

Lakshmi Kosaraju, S., Weerakkody, R., Augustin, M.A. (2010). Chitosan-glucose conjugates: influence of extent of Maillard reaction on antioxidant properties. Journal of Agricultural and Food Chemistry, 58, 12449-12455.

Leceta, I., Guerrero, P., Ibarburu, I., Dueñas, M.T., de la Caba, K. (2013). Characterization and antimicrobial analysis of chitosan-based films. Journal of Food Engineering, 116, 889899.

Liu, J., Sun, L., Xu, W., Wang, Q., Yu, S., Sun, J. (2019). Current advances and future perspectives of 3D printing natural-derived biopolymers. Carbohydrate Polymers, 207, 297-316.

Mahmoudi, N., Ostadhossein, F., Simchi, A. (2016). Physicochemical and antibacterial properties of chitosan-polyvinylpyrrolidone films containing self-organized graphene oxide nanolayers. Journal of Applied Polymer Science, 133, 43194.

Matiacevich, S.B., Pilar Buera, M. (2006). A critical evaluation of fluorescence as a potential marker for the Maillard reaction. Food Chemistry, 95, 423-430.

Mujeeb Rahman, P., Abdul Mujeeb, V.M., Muraleedharan, K., Thomas, S.K. (2018). Chitosan/nano $\mathrm{ZnO}$ composite films: Enhanced mechanical, antimicrobial and dielectric properties. Arabian Journal of Chemistry, 11, 120-127. 
Mujtaba, M., Morsi, R.E., Kerch, G., Elsabee, M.Z., Kaya, M., Labidi, J., Khawar, K.M. (2019). Current advancements in chitosan-based film production for food technology; A review. International Journal of Biological Macromolecules, 121, 889-904.

Park, S.B., Lih, E., Park, K.S., Joung, Y.K., Han, D.K. (2017). Biopolymer-based functional composites for medical applications. Progress in Polymer Science, 68, 77-105.

Prameela, K., Mohan, C.M., Ramakrishna, C. (2018). Chapter 1 - Biopolymers for Food Design: Consumer-Friendly Natural Ingredients. In: Grumezescu, A.M. (Eds.), Biopolymers for Food Design-Handbook of Food Bioengineering (pp. 1-32). Elsevier Inc.

Rubentheren, V., Ward, T.A., Chee, C.Y., Nair, P., Salami, E., Fearday, C. (2016). Effects of heat treatment on chitosan nanocomposite film reinforced with nanocrystalline cellulose and tannic acid. Carbohydrate Polymers, 140, 202-208.

Rui, L., Xie, M., Hu, B., Zhou, L., Yin, D., Zeng, X. (2017). A comparative study on chitosan/gelatin composite films with conjugated or incorporated gallic acid. Carbohydrate Polymers, 173, 473-481.

Serrano-Leon, J.S., Bergamaschi, K.B., Yoshida, C.M.P., Saldana, E., Selani, M.M., RiosMera, J.D., Alencar, S.M., Contreras-Castillo, C.J. (2018). Chitosan active films containing agro-industrial residue extracts for shelf life extension of chicken restructured product. Food Research International, 108, 93-100.

Shariatinia, Z. (2018). Carboxymethyl chitosan: Properties and biomedical applications. International Journal of Biological Macromolecules, 120, 1406-1419.

Souza, V.G.L., Fernando, A.L., Pires, J.R.A., Rodrigues, P.F., Lopes, A.A.S., Braz Fernandes, F.M. (2017). Physical properties of chitosan films incorporated with natural antioxidants. Industrial Crops \& Products, 107, 565-572.

Stevenson, M., Long, J., Seyfoddin, A., Guerrero, P., de la Caba, K., Etxabide, A. (2020). Characterization of ribose-induced crosslinking extension in gelatin films. Food Hydrocolloids, 99, 105324.

Su, J.F., Yuan, X.Y., Huang, Z., Wang, X.Y., Lu, X.Z., Zhang, L.D., Wang, S.B. (2012). Physicochemical properties of soy protein isolate/carboxymethyl cellulose blend films crosslinked by Maillard reactions: Color, transparency and heat-sealing ability. Materials Science and Engineering: C, 32, 40-46.

Sung, W.C., Chang, Y.W., Chou, Y.H., Hsiao, H. (2018). The functional properties of chitosanglucose-asparagine Maillard reaction products and mitigation of acrylamide formation by chitosans. Food Chemistry, 243, 141-144.

Umemura, K., Kawai, S. (2007). Modification of chitosan by the Maillard reaction using cellulose model compounds. Carbohydrate Polymers, 68, 242-248.

Umemura, K., Kawai, S. (2008). Preparation and characterization of Maillard reacted chitosan films with hemicellulose model compounds. Journal of Applied Polymer Science, 108, 2481-2487.

Vilela, C., Kurek, M., Hayouka, Z., Röcker, B., Yildirim, S., Antunes, M.D.C., Nilsen-Nygaard, J., Pettersen, M.K., C.S.R. Freire. (2017). A concise guide to active agents for active food packaging. Trends in Food Science \& Technology, 80, 212-222.

Vlacha, M., Giannakas, A., Katapodis, P., Stamatis, H., Ladavos, A., Barkoula, N.M. (2016). On the efficiency of oleic acid as plasticizer of chitosan/clay nanocomposites and its role on thermo-mechanical, barrier and antimicrobial properties - comparison with glycerol. Food Hydrocolloids, 57, 10-19.

Wang, Y., Liu, F., Liang, C., Yuan, F., Gao, Y. (2014). Effect of Maillard reaction products on the physical and antimicrobial properties of edible films based on $\varepsilon$-polylysine and chitosan. Journal of the Science of Food and Agriculture, 94, 2986-2991. 
Wu, S., Hu, J., Wei, L., Du, Y., Shi, X., Zhang, L. (2014). Antioxidant and antimicrobial activity of Maillard reaction products from xylan with chitosan/chitooligomer/glucosamine hydrochloride/taurine model systems. Food Chemistry, 148, 196-203.

Xu, Z.Z., Huang, G.Q., Xu, T.C., Liu, L.N., Xiao, J.X. (2019). Comparative study on the Maillard reaction of chitosan oligosaccharide and glucose with soybean protein isolate. International Journal of Biological Macromolecules, 131, 601-607.

Yildirim, A., Mavi, A., Kara, A.A. (2001). Determination of antioxidant and antimicrobial activities of Rumex crispus L. extracts. Journal of Agricultural and Food Chemistry, 49, 4083-4089.

Zhai, L., Bai, Z., Zhu, Y., Wang, B., Luo, W. (2018). Fabrication of chitosan microspheres for efficient adsorption of methyl orange. Chinese Journal of Chemical Engineering, 26, 657-666.

Zhang, H., Yang, J., Zhao, Y. (2015). High intensity ultrasound assisted heating to improve solubility, antioxidant and antibacterial properties of chitosan-fructose Maillard reaction products. LWT - Food Science and Technology, 60, 253-262.

Zhang, N., Chen, H., Zhang, Y., Ma, L., Xu, X. (2013). Comparative studies on chemical parameters and antioxidant properties of stipes and caps of shiitake mushroom as affected by different drying methods. Journal of the Science of Food and Agriculture, 93, 31073113.

Zhong, L., Ma, N., Wu, Y., Zhao, L., Ma, G., Pei, F., Hu, Q. (2019). Characterization and functional evaluation of oat protein isolate-Pleurotus ostreatus $\beta$-glucan conjugates formed via Maillard reaction. Food Hydrocolloids, 87, 459-469. 
Click here to download Supplementary data: Supplementary Data CP R2.pdf

df

(1)

(1)
(1) (1) (1) (1) (1) (2) (1) (1) (n) (2) (n) (2) (1) (n) (n) (2) (2) (n) (2) (2) (2) (n) (n) (n) (2) (2) (1) (1)

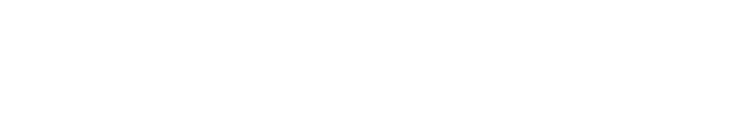

.

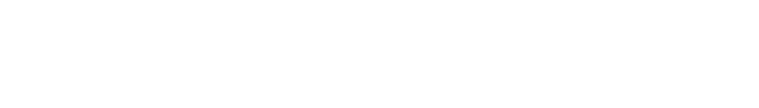

-




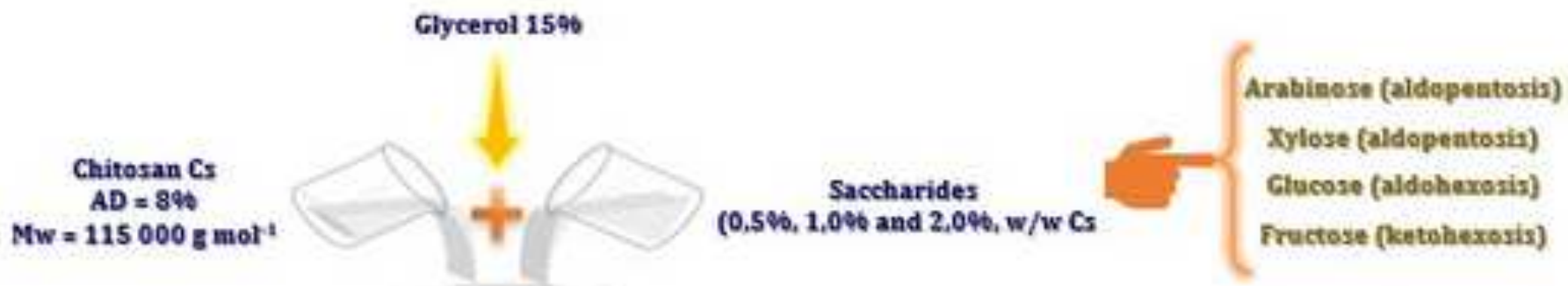

$48 \mathrm{~h}, 25^{\circ} \mathrm{C}$

\section{Cs-saccharides films}

\section{Maillard Reaction}

$24 \mathrm{~h}$
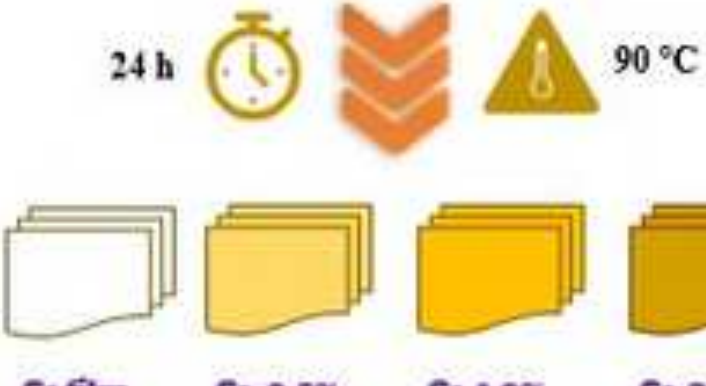

Cs film

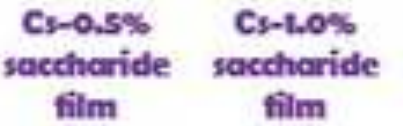

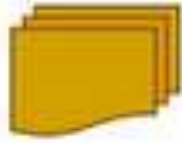

Cs-2.0\%

sactharide

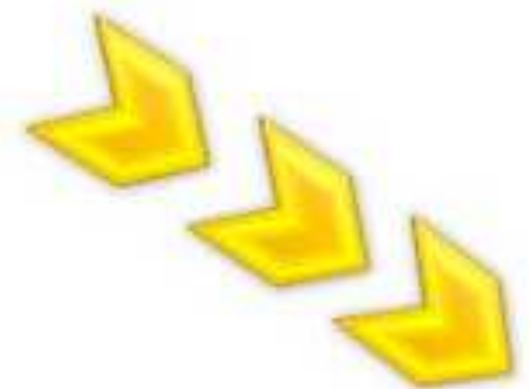

film
- Water resistance

- Water barrier

- Light barrier

- Color parameters

- Mechanical properties

- Thermal resistance

- Antioxidant activities

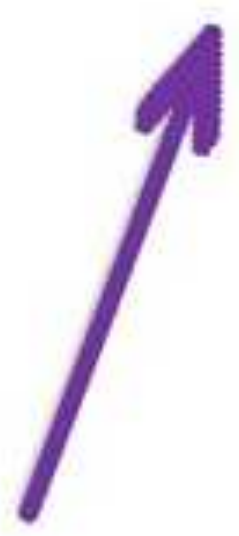


Sfax, $01^{\text {th }}$ of March 2020

\section{Credit author statement}

Marwa HAMDI: Conceptualization, Methodology, Validation, Formal analysis, Investigation, Writing-Editing, Visualization.

Rim NASRI: Resources, Supervision.

Youssra BEN AZAZA: Investigation.

Suming LI: Resources, Supervision.

Moncef NASRI: Resources, Supervision, Review.

\section{Dr. Marwa HAMDI}

Laboratory of Enzymatic Engineering and Microbiology, National School of Engineers of Sfax, Sfax. B.P.1173, 3038 Sfax, Tunisia.

E-mail: marwahamdi50@yahoo.fr 